Article

\title{
Interpretation of the Reflectance Spectra of Lithium (Li) Minerals and Pegmatites: A Case Study for Mineralogical and Lithological Identification in the Fregeneda-Almendra Area
}

\author{
Joana Cardoso-Fernandes ${ }^{1,2, *(\mathbb{})}$, João Silva ${ }^{1}$, Mônica M. Perrotta ${ }^{3}\left(\right.$, Alexandre Lima ${ }^{1,2} \oplus$, Ana C. Teodoro ${ }^{1,2}{ }^{(0)}$,

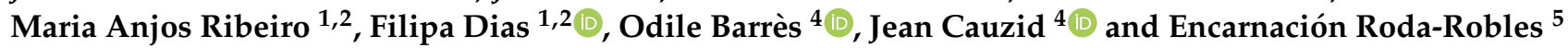 \\ 1 Department of Geosciences, Environment and Spatial Plannings, Faculty of Sciences, University of Porto, \\ Rua Campo Alegre, 4169-007 Porto, Portugal; up201503357@fc.up.pt (J.S.); allima@fc.up.pt (A.L.); \\ amteodor@fc.up.pt (A.C.T.); maribeir@fc.up.pt (M.A.R.); filipa.dias@fc.up.pt (F.D.) \\ 2 ICT (Institute of Earth Sciences)-Porto pole (Portugal), Rua Campo Alegre, 4169-007 Porto, Portugal \\ 3 Remote Sensing and Mineral Spectroscopy Laboratory, Geological Survey of Brazil (CPRM), Rua Costa, 55, \\ São Paulo 01304-010, Brazil; monica.perrotta@cprm.gov.br \\ 4 GeoRessources Laboratory, Université de Lorraine, CNRS, F-54000 Nancy, France; \\ odile.barres@univ-lorraine.fr (O.B.); jean.cauzid@univ-lorraine.fr (J.C.) \\ check for \\ updates \\ Citation: Cardoso-Fernandes, J.; \\ 5 Departamento de Geología, Universidad del País Vasco (UPV/EHU), Barrio Sarriena s/n, 48940 Leioa, Spain; \\ encar.roda@ehu.es \\ * Correspondence: joana.fernandes@fc.up.pt
} Silva, J.; Perrotta, M.M.; Lima, A.; Teodoro, A.C.; Ribeiro, M.A.; Dias, F.; Barrès, O.; Cauzid, J.; Roda-Robles, E. Interpretation of the Reflectance Spectra of Lithium (Li) Minerals and Pegmatites: A Case Study for Mineralogical and Lithological Identification in the FregenedaAlmendra Area. Remote Sens. 2021, 13, 3688. https://doi.org/10.3390/ rs13183688

Academic Editors: Prasad

S. Thenkabail and Amin

Beiranvand Pour

Received: 30 May 2021

Accepted: 12 September 2021

Published: 15 September 2021

Publisher's Note: MDPI stays neutral with regard to jurisdictional claims in published maps and institutional affiliations.

Copyright: (c) 2021 by the authors. Licensee MDPI, Basel, Switzerland. This article is an open access article distributed under the terms and conditions of the Creative Commons Attribution (CC BY) license (https:// creativecommons.org/licenses/by/ $4.0 /)$.
Abstract: Reflectance spectroscopy has been used to identify several deposit types. However, applications concerning lithium (Li)-pegmatites are still scarce. Reflectance spectroscopic studies complemented by microscopic and geochemical studies were employed in the Fregeneda-Almendra (Spain-Portugal) pegmatite field to analyze the spectral behavior of Li-minerals and field lithologies. The spectral similarity of the target class (Li-pegmatites) with other elements was also evaluated. Lepidolite was discriminated from other white micas and the remaining Li-minerals. No diagnostic feature of petalite and spodumene was identified, since their spectral curves are dominated by clays. Their presence was corroborated (by complementary techniques) in petalite relics and completely replaced crystals, although the clay-related absorption depths decrease with Li content. This implies that clays can be used as pathfinders only in areas where argillic alteration is not prevalent. All sampled lithologies present similar water and/or hydroxide features. The overall mineral assemblage is very distinct, with lepidolite, cookeite, and orthoclase exclusively identified in Li-pegmatite (being these minerals crucial targets for Li-pegmatite discrimination in real-life applications), while chlorite and biotite can occur in the remaining lithologies. Satellite data can be used to discriminate Lipegmatites due to distinct reflectance magnitude and mineral assemblages, higher absorptions depths, and distinct $\mathrm{Al}-\mathrm{OH}$ wavelength position. The potential use of multi- and hyperspectral data was evaluated; the main limitations and advantages were discussed. These new insights on the spectral behavior of Li-minerals and pegmatites may aid in new Li-pegmatite discoveries around the world.

Keywords: remote sensing; reflectance spectroscopy; hyperspectral; geological exploration; spectral library; absorption features; spectral mineralogy; pegmatite; lithium

\section{Introduction}

Reflectance spectroscopy studies have shown a relevant economic potential to mineral exploration, either through the direct characterization and identification of the mineralogy of the deposits or through the identification of hydrothermal alteration zonation as a proxy to target mineralizations such as (i) porphyry copper deposits [1], (ii) volcanogenic massive sulfide (VMS) deposits [2,3], (iii) rare-earth element (REE) deposits [4,5], (iv) 
zinc-lead-silver deposits [6], (v) iron oxide-copper-gold (IOCG) deposits [7], and (vi) gold deposits [8].

Similar approaches have been applied to distinct deposit types like pegmatites that have a high economic interest for (i) ceramic components such as quartz and feldspar; (ii) rare, critical metals such as lithium (Li), tin ( $\mathrm{Sn}$ ), tantalum $(\mathrm{Ta})$, cesium $(\mathrm{Cs})$, beryllium (Be), and rubidium ( $\mathrm{Rb})$; as well as for (iii) colored gemstones [9-14]. Zhang et al. [15] developed a systematic spectroscopic characterization of tourmalines from the Koktokay No.3 pegmatite (northwestern China), the pegmatite contact wall zone, and from the host rocks, which included several methods, including reflectance spectroscopy. These methods, coupled with mineral chemistry analyses, allowed to better understand the magmatic to hydrothermal evolution of the pegmatite and the fluid interaction with the pegmatite and the country rocks. Carrino et al. [16] correlated an electron probe microanalysis (EPMA) with the reflectance spectra of elbaite (Li-tourmaline) gemstones from pegmatites of the Seridó Pegmatite Province (Northeastern Brazil). In the end, the application of statistical techniques, such as principal component analysis (PCA), discriminated tourmalines of different compositions based on the reflectance spectra. Bocchio et al. [17] used geochemical and spectroscopic techniques such as reflectance spectroscopy to achieve a gemological characterization of aquamarine (blue beryl) samples from granitic pegmatites of the MasinoBregaglia Massif, Central Alps, Italy. Araújo Neto et al. [18] undertook a similar but more complete study to characterize emerald (green beryl) crystals from granitic aplite and pegmatite veins in the Paraná deposit (Northeastern Brazil), using mineral chemistry, absorption and reflectance spectroscopy, and thermal analysis. Silva et al. [19] explored the potential of reflectance spectroscopy to characterize the mineral phases of the Alto do Giz pegmatite in the Seridó Pegmatite Province (Northeastern Brazil). To complement the interpretation of the reflectance spectra, scanning electron microscopy (SEM) and X-ray diffraction (XRD) were used. Despite the intense kaolinization, hydrothermal-metasomatic and supergene alteration overprinting the rock bulk mineralogy, reflectance spectroscopy proved to be capable of defining the internal zonation of the pegmatite.

Although the literature shows that reflectance spectroscopy is successfully applicable to pegmatite deposits, study applications are still scarce. Moreover, this technique can be of considerable importance if applied to vector pegmatites with economic potential for rare and strategic metals like Li. The increasing economic significance of $\mathrm{Li}$ triggered several satellite-based exploration works that allowed identifying Li-pegmatites correctly worldwide and that lead to the discovery of pegmatite-hosted Li deposits [20-24]. Costa et al. [25] were the first authors to apply reflectance spectroscopy exclusively for Li-mineral identification and associated weathering alteration minerals in the Jequitinhonha region (Brazil). Despite showing promising results for minerals like spodumene or lepidolite, it was not possible to identify petalite and zinnwaldite through their spectral signatures. Moreover, the supergene alteration minerals seem to be related to the semi-arid climate of the region [25], which differs from Europe's climate conditions, highlighting the need for a similar approach in European territory.

Considering this, the study area chosen for this work is the Fregeneda-Almendra region, one of the largest European provinces in Li production [11]. In this region, the Libearing minerals with greater economic interest are spodumene $\left(\mathrm{LiAlSi}_{2} \mathrm{O}_{6}\right.$; pyroxene; $8.03 \%$ $\left.\mathrm{Li}_{2} \mathrm{O}\right)$, petalite $\left(\mathrm{LiAlSi}_{4} \mathrm{O}_{10} ;\right.$ feldspathoid; $\left.4.5 \% \mathrm{Li}_{2} \mathrm{O}\right)$, and lepidolite $\left(\mathrm{K}(\mathrm{Li}, \mathrm{Al})_{3}(\mathrm{Si}, \mathrm{Al})_{4} \mathrm{O}_{10}\right.$ $\left.(\mathrm{F}, \mathrm{OH})_{2}\right)$; mica; $\left.7.7 \% \mathrm{Li}_{2} \mathrm{O}\right)[13,26,27]$. This study delineated the following objectives: (i) build a spectral library dedicated to Li-bearing minerals and understand their respective spectral signatures, (ii) extend the spectral library to other lithologies that occur in the study area to enable satellite-based lithological classification, and (iii) evaluate if there can be any spectral confusion between the target class (Li-pegmatite) and other within-scene elements, as verified by Cardoso-Fernandes et al. [28]. Therefore, this research presents a complete view of the use of reflectance spectroscopy for laboratory identification of Li-bearing minerals and remote sensing mapping of Li-pegmatites, including spectral data acquired in a preliminary phase $[29,30]$, as well as new spectral measurements and complementary 
geochemical, petrographic, and mineralogical studies. The combination of classical and uncommon analytical techniques allowed characterizing the mineral assemblage resulting from the alteration of petalite crystals, and the paragenesis of some of the collected rock samples. Overall, this study addresses different pertinent research questions: (i) Are Li-bearing minerals distinguishable from each other and other minerals? (ii) How can the alteration products affect the spectral signature of Li-bearing minerals? (iii) Can Lipegmatites be spectrally discriminated from other lithologies in a supervised classification attempt? The results obtained are essential to better direct future remote sensing-based exploration studies. They provide new insights on the spectral behavior of Li-minerals and Li-pegmatites, allowing to identify which minerals can be directly discriminated against while proposing, for the first time, relevant pathfinders to distinguish other Li-minerals, as well as Li-pegmatites. The main implications of this study may lead to new Li-pegmatite discoveries in Europe and worldwide.

\section{Study Area and Field Surveys}

The field surveys were conducted on the Fregeneda-Almendra aplite-pegmatite field (Figure 1), spreading from La Fregeneda (Spain) to Almendra (Portugal). The pegmatite field contains 11 different types of dikes ranging from barren to more evolved: $\mathrm{Li}, \mathrm{F}, \mathrm{Sn}, \mathrm{Rb}$, $\mathrm{Nb}>\mathrm{Ta}, \mathrm{B}$, and P-enriched bodies [26,27,31]. Among the more evolved dikes, there are four types containing Li mineralization: (i) petalite-rich dikes (exploited in the Bajoca open-pit mine), (ii) spodumene-rich dikes (exploited in the Alberto open-pit mine), (iii) lepidolitebearing dikes, and (iv) lepidolite + spodumene-bearing dikes (exploited in the Feli open-pit mine) $[26,27,31]$. All Li-rich pegmatite dikes are emplaced in a pre-Ordovician metasedimentary belt composed of a pelitic-sandy flysch series, Complexo Xisto-Grauváquico (CXG) [32-34]. Additionally, the fractionation degree of the pegmatite dikes increases with further distance to the syn-Variscan granitoid rocks (granites and granodiorite) of the Figueira de Castelo Rodrigo-Lumbrales Anatectic Complex [26,27,31,35-37] (Figure 1). These granitoids correspond to S-type, two-mica granites with several facies, showing distinct grain sizes (from fine to coarse-grained), and to a fine-to-medium-grained, essentially biotitic, granodiorite [36-38]. In the Fregeneda-Almendra region, there are also Ordovician phyllitic-quartzitic formations, as well as Cenozoic sedimentary deposits (Figure 1).

During the field surveys, samples were collected at several distinct field stations according to the aforementioned goals (Figure 1). To construct the Li-mineral database, petalite, spodumene, and lepidolite hand specimens were retrieved from different types of mineralized dikes either in open-pit mines or at unexploited locations. In general, spodumene was under-sampled in comparison with the other Li-minerals. To fill this gap, existing samples from Feli and Alberto mines (Figure 1), as well as from other locations in the Fregeneda-Almendra field, as part of a mineralogical collection at the University of Porto, were also included in this study, bringing the number of samples to a total of 28 . Considering the future satellite-based lithological classification attempts, the various field lithologies (Li-pegmatite, metasediments, and granitoids) were also sampled to conduct further laboratory spectral analysis. The field stations included, whenever possible, several open-pit mines to ensure that the different lithologies presented large and fresh expositions to serve as possible training areas for supervised classification. These field campaigns allowed refining and improving the training areas used in preliminary image classification attempts [28]. Additionally, some of the areas misclassified as Li-pegmatite in this preliminary classification were sampled to evaluate the degree of spectral similarity between these areas and Li-pegmatites. In the field, the exposed material in these misclassified areas was assessed, and a field description of each site was made. 


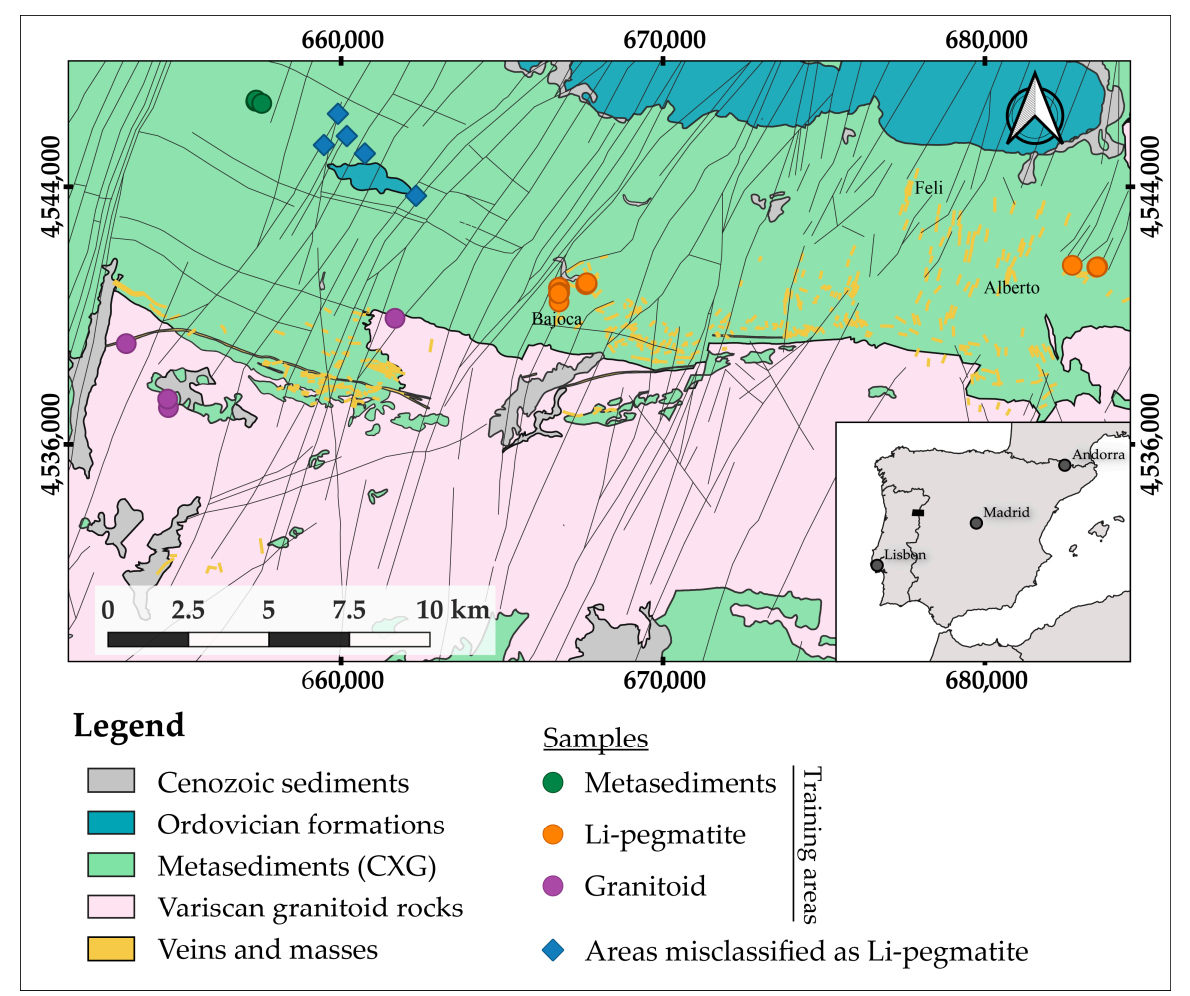

Figure 1. Location of the study area in the Iberian Peninsula and geological setting of the FregenedaAlmendra pegmatite field (adapted from References $[26,39,40]$ ). The field stations where the samples were collected are marked with a circle for the training areas (the color is dependent on the sample type) and with a diamond for the areas misclassified as Li-pegmatite using machine learning algorithms. Li-mineral specimens were also collected in Li-pegmatite sites. Map projection: Universal Transverse Mercator zone 29N from the WGS84 datum.

\section{Methodology}

\subsection{Reflectance Spectroscopy Studies}

The spectral studies were conducted in the laboratory employing two distinct spectroradiometers, both covering the spectral range between 350 and $2500 \mathrm{~nm}$ : (i) the ultrahigh-resolution SR-6500 (Spectral Evolution, Inc.) equipment (1.5 nm @ 700 nm, 3.0 nm @ $1500 \mathrm{~nm}$, and $3.8 \mathrm{~nm} @ 2100 \mathrm{~nm}$ ) and (ii) the FieldSpec 4 (ASD, Inc.) standard resolution equipment (3.0 nm @ 700 nm, 10.0 nm @ 1400 nm, and 10.0 nm @ 2100 nm). In each case, the point spectral measurements were performed using a Contact Probe with similar characteristics, namely an internal light source provided by a halogen bulb and spot size of $10 \mathrm{~mm}$. For reflectance calibration, a Spectralon (Labsphere) plate with a maximum reflectance above $95 \%$ for the $250-2500-\mathrm{nm}$ range and above $99 \%$ for the $400-1500-\mathrm{nm}$ region. Small (less than $2 \mathrm{~cm}$ ) or friable samples were analyzed over the white plate. When using either of the spectroradiometers, each measurement corresponded to an average of 40 scans. For the FieldSpec 4 equipment, four additional spectra were acquired in each analyzed spot, later averaged into a final spectrum, to increase the signal-to-noise ratio.

ASD ViewSpec Pro ${ }^{\mathrm{TM}}$ software [41] and SpectraGryph software [42] were used to individually analyze all spectra to exclude measurement errors or spectra with noticeable noise caused by vegetation fragments on the surface of the samples and for spectra averaging. Point measurements belonging to the same sample and with similar spectral behavior were averaged to aid visualization and allow fast interpretation of the spectra. The final Li-minerals spectral library contains reference data from 28 samples (five spodumene, 13 petalite, and ten lepidolite samples). Moreover, to complete the spectral studies for lithological classification, 45 samples from possible training areas were analyzed (five from CXG metasediments, 33 from distinct Li-pegmatite types, and seven from granitoid rocks), 
as well as 11 samples from four areas misclassified as Li-pegmatite. All samples and point measurements were photographed.

The laboratory acquired spectra were normalized through continuum removal [43] to compare the spectra obtained by both spectroradiometers and enhance the spectral absorption features. In this case, a hull quotient was calculated after automatically fitting a convex-hull to each spectrum in a Python environment using the pysptools library [44]. The extraction of the wavelength, depth, and other geometric parameters of the absorption features was made using SpectraGryph software and the pysptools library. The complete spectral library and additional information on the equipment used and spectra processing can be found in Cardoso-Fernandes et al. $[45,46]$.

\subsection{Complementary Petrographic and Geochemical Studies}

Microscopic studies were conducted at the University of Porto, using a transmitted light Nikon petrographic microscope (Eclipse E 400 POL), coupled with a ZEISS Axiocam camera for both the petalite alteration products and the samples from the four areas misclassified as Li-pegmatite. Selected petalite samples with distinct degrees of alteration were crushed to quantify their Li content at Activation Laboratories Ltd. (Actlabs), ON, Canada, using the Code 8-Lithium Ore analytical package. Sample preparation and crushing were conducted at the University of Porto using manual and automated mortar agate grinders (Retsch RM 200). Li quantification was achieved through inductively coupled plasma-optical emission spectrometry (ICP-OES) after four-acid digestion (detection limit $0.001 \%)$. Afterward, $\mathrm{Li}$ contents were converted to $\mathrm{Li}_{2} \mathrm{O}(\%)$ using a compound ratio of 2.1527. Mineralogical information was obtained through powder X-ray diffraction (XRD) for friable samples and through optical microscopy and Scanning Electron Microscopy with Energy Dispersive Spectroscopy (SEM-EDS) for hard rock samples. The XRD analysis was performed at the National Laboratory of Energy and Geology (LNEG, Portugal) using a Panalytical Diffractometer XPERT-PRO, equipped with a PW3050/60 goniometer, with a Theta-2Theta geometry and X-ray tube with a copper $(\mathrm{Cu})$ anticathode. The tube voltage and current were set to $45 \mathrm{kV}$ and $40 \mathrm{~mA}$, respectively. Regarding the acquisition settings, a continuous scan mode with a scan range between $3^{\circ}$ and $90^{\circ}$ of 2 teta, a step size of $0.0084^{\circ}$, and $4.960 \mathrm{~s}$ of counting time per step was used. The SEM-EDS studies were conducted at the University of Porto, in previously carbon-coated thin sections, using a Hitachi FlexSEM 1000 SEM coupled to a Bruker QUANTAX EDS system.

\section{Results}

In this section, selected spectra from the spectral library are presented, taking into account the previously designated goals. The main mineralogy inferred from the spectra is presented, but a detailed analysis spectrum per spectrum can be found in the Supplementary Materials (Tables S1-S3).

\subsection{Li-Minerals Spectral Database}

The spectral database was built for three distinct Li-minerals: lepidolite (Figure 2), spodumene (Figure 3), and petalite (Figure 4). For this study, monomineralic samples were preferred to rock samples to avoid the interference of other minerals. As can be seen in Figure 2, all lepidolite spectra show the white mica typical features due to the hydroxide ion $\left(\mathrm{OH}^{-}\right)$absorption around $\sim 1409 \mathrm{~nm}$ associated with the principal, sharp Al-OH absorption feature (between $2195 \mathrm{~nm}$ and $2205 \mathrm{~nm}$ ) and the Al-OH secondaries (around $\sim 2348 \mathrm{~nm}$ and $\sim 2435 \mathrm{~nm}$, respectively) [47-49]. Other white mica-related, weak absorption features located $\sim 1537 \mathrm{~nm}, \sim 2002 \mathrm{~nm}$, and $\sim 2114 \mathrm{~nm}$ are due to $\mathrm{OH}^{-}$and $\mathrm{OH}^{-}$combined with lattice modes $[49,50]$. The depth of the water feature $(\sim 1909 \mathrm{~nm})$ decreases from Figure $2(\mathrm{a}-\mathrm{c})$, and the slight inflection around $1460 \mathrm{~nm}$ indicates that montmorillonite is also present, mixed with white mica features [1,49]. The remaining spectra ( $\mathrm{d}-\mathrm{k})$ have higher purity, allowing to characterize the lepidolite due to: (i) a peak in the red region, caused by lepidolite purple color and (ii) multiple absorption features 
in the visible and near-infrared (VNIR) region, together with the drop off to extreme blue observed in the raw reflectance curves (left panel of Figure 2). These features are interpreted to be related to ferric iron $\left(\mathrm{Fe}^{3+}\right)$ and manganese $\left(\mathrm{Mn}^{3+}\right)$ incorporated into the structure of lepidolite [50]. Ferrous iron $\left(\mathrm{Fe}^{2+}\right)$ may cause the absorption at $720 \mathrm{~nm}$ (Figure $\left.2(\mathrm{e})\right)[16,51]$.
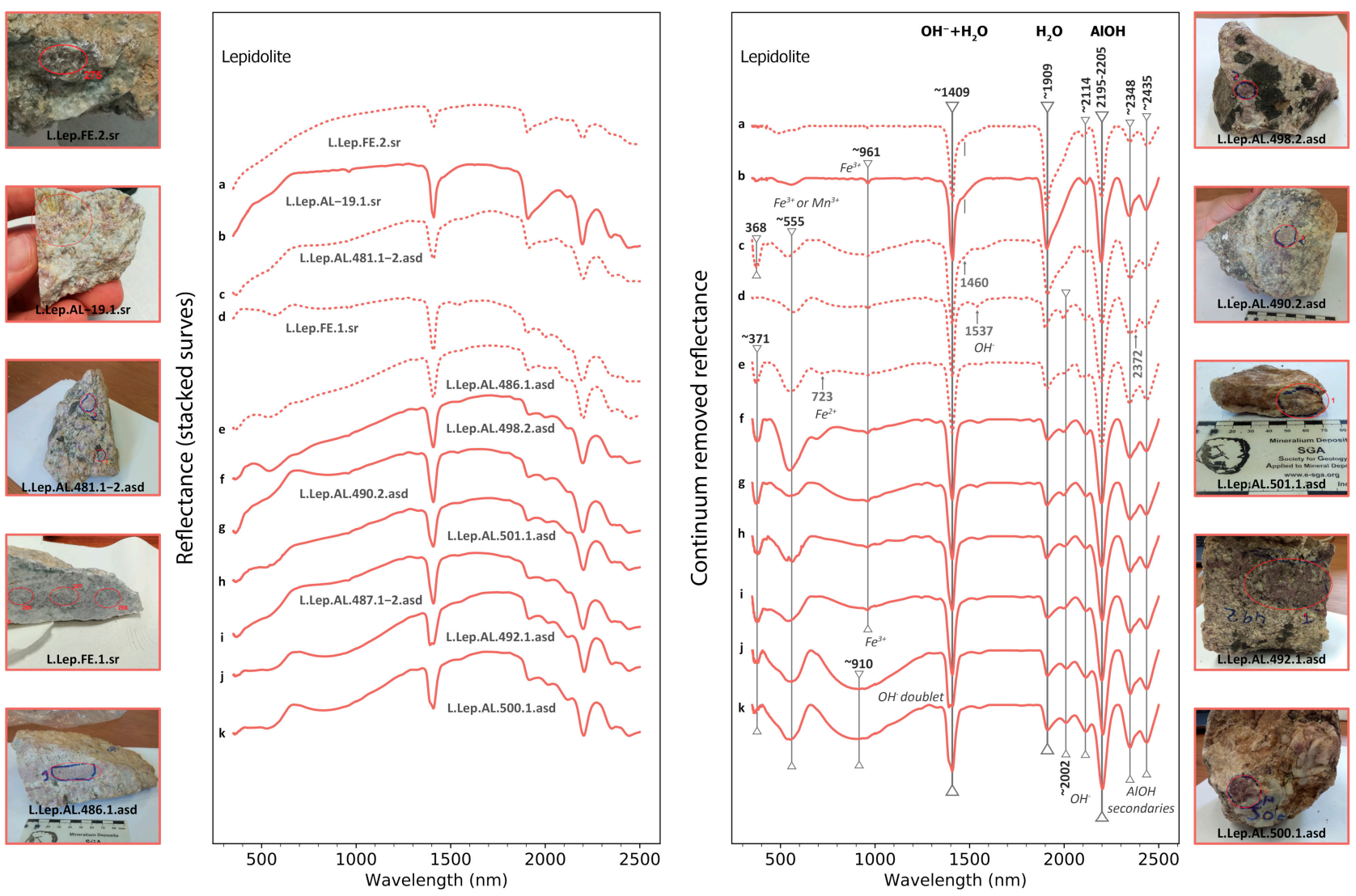

Figure 2. Spectral signature of lepidolite (Li-bearing mica): reflectance curves (to the left) and continuum removed curves (to the right). The main absorption features are highlighted, and sample photographs are provided. Each spectrum has a database code [45] providing information about the type of sample (L-Li-bearing minerals), mineralogy (Leplepidolite), sample provenance (FE-Feli mine and AL-Almendra), a three-digit numerical part representing the GPS code, a one- or two-digit code representing the spectra number or the averaged spectra numbers, and a reference to the spectroradiometer employed (sr-SR-6500; asd-FieldSpec 4). Dotted curves: fresh samples; full curves: samples with visible signs of weathering.

The reference spectral data of spodumene was acquired considering pure or spodumene intergrowth with quartz. Despite this, it is not expected that the associated quartz will obscure the spectral behavior of spodumene because the main diagnostic features of the former do not occur in the VNIR and shortwave infrared (SWIR) regions [47,52]. Figure 3 shows the main absorption features located around $\sim 1414 \mathrm{~nm}, \sim 1910 \mathrm{~nm}$, and $\sim 2209 \mathrm{~nm}$ for spodumene + quartz samples and around $\sim 1412 \mathrm{~nm}, \sim 1913 \mathrm{~nm}$, and $\sim 2205 \mathrm{~nm}$ for spodumene samples. The presence of molecular water is evidenced by the broader, asymmetric features approximately at $\sim 1410 \mathrm{~nm}\left(\mathrm{OH}^{-}+\mathrm{H}_{2} \mathrm{O}\right)$ and $\sim 1910 \mathrm{~nm}\left(\mathrm{H}_{2} \mathrm{O}\right)[48,52]$. Molecular water associated with (i) higher depth of the water feature in comparison with the Al-OH fundamental absorption (around $\sim 2200 \mathrm{~nm}$ ) and (ii) a slight inflection around $\sim 1467 \mathrm{~nm}$ are diagnostic of smectite minerals—in particular, of montmorillonite [1,48,49]. The shallow Al-OH secondaries at $\sim 2350 \mathrm{~nm}$ and $\sim 2437 \mathrm{~nm}$ for spodumene + quartz, and at $\sim 2352 \mathrm{~nm}$ and $\sim 2440 \mathrm{~nm}$ for spodumene, indicate the existence of illite mixed with montmorillonite and possibly kaolinite [48,49]. Iron incorporation $\left(\mathrm{Fe}^{3+}\right.$ and possibly $\left.\mathrm{Fe}^{2+}\right)$ into both spodumene and spodumene + quartz samples could be identified due to: (i) the drop off to the blue observed in the reflectance curves (left panel of Figure 3) [50] and 
(ii) a slight inflection around $\sim 2240 \mathrm{~nm}$ related with the Fe-OH bond [49] (Figure $3(\mathrm{a}-\mathrm{h})$ ). Spectra h-k show additional features diagnostic of kaolinite, such as (i) a small inflection around $\sim 2165 \mathrm{~nm}$ and (ii) the presence of an Al-OH triplet at $\sim 2312, \sim 2350$, and $\sim 2380 \mathrm{~nm}[8,48,49,53]$.
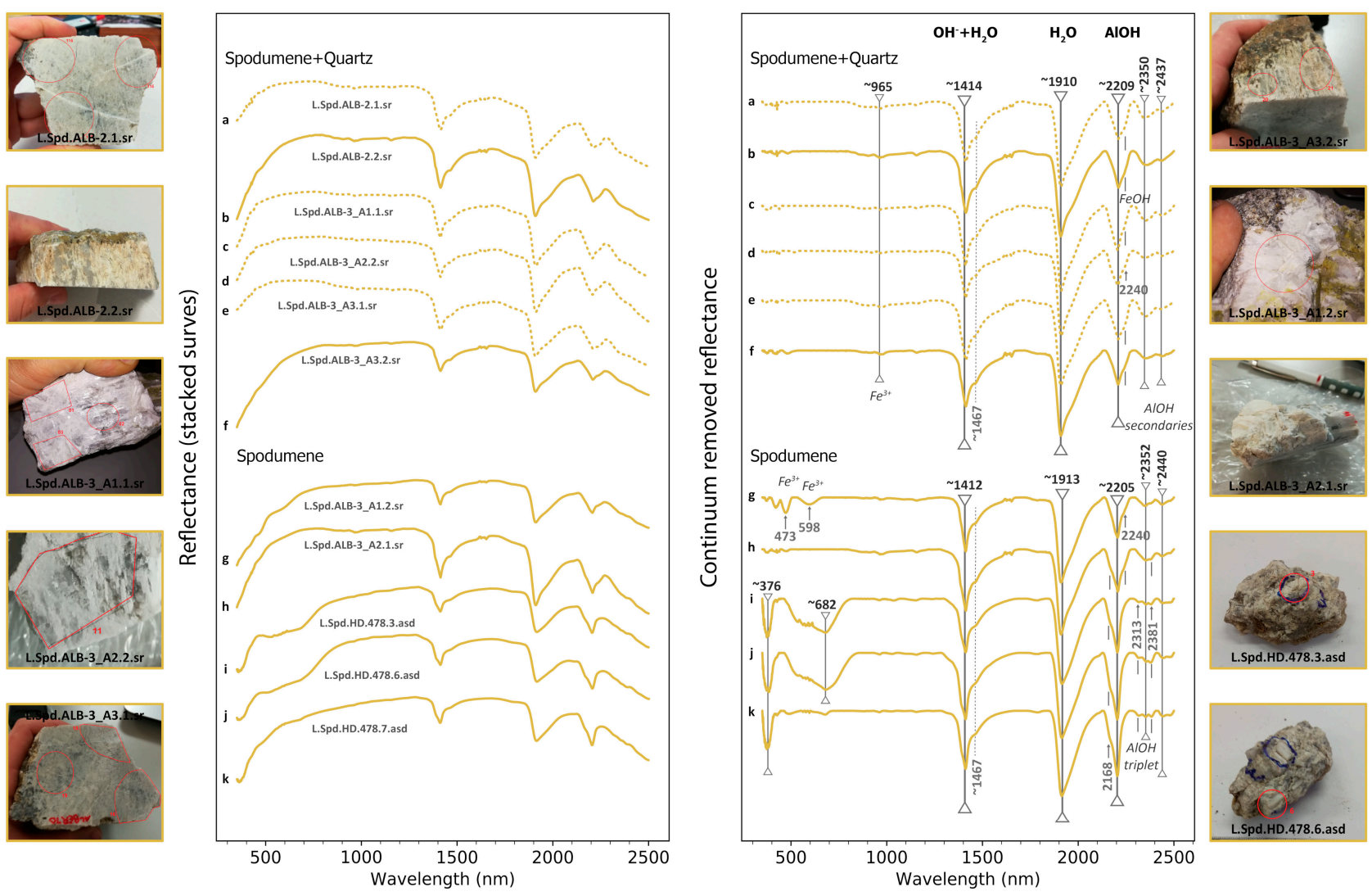

Figure 3. Spectral signature of spodumene (a Li-bearing pyroxene): reflectance curves (to the left) and continuum removed curves (to the right). The main absorption features are highlighted, and sample photographs are provided. Dotted curves: fresh samples; full curves: samples with visible signs of weathering. Each spectrum has a database code [45] providing information about the type of sample (L—Li-bearing minerals), mineralogy (Spd—spodumene), sample provenance (ALBAlberto mine and HD-Hinojosa de Duero), a three-digit numerical part representing the GPS code, a one- or two-digit code representing the spectra number or the averaged spectra numbers, and a reference to the spectroradiometer employed (sr-SR-6500; asd-FieldSpec 4).

Most petalite spectra (Figure 4) are very similar to spodumene, showing the same main absorptions (Figure $4(\mathrm{a}-\mathrm{q})$ ). Montmorillonite is identified in all samples by the broad, asymmetric, and acute absorptions around $\sim 1413 \mathrm{~nm}$ and $\sim 1911 \mathrm{~nm}$, associated with the Al-OH feature at $2206 \mathrm{~nm}[48,49]$, shallower than the $1911 \mathrm{~nm}$ one, and the slight inflection around $\sim 1467 \mathrm{~nm}[1,49]$. It is the sole mineral identified in spectra a-c, $\mathrm{e}$, and $\mathrm{o}-\mathrm{q}$ (Figure 4). Others ( $\mathrm{d}$ and $\mathrm{g}-\mathrm{n}$ ) show additional shallow Al-OH secondary absorptions at $\sim 2356 \mathrm{~nm}$ and $\sim 2445 \mathrm{~nm}$, indicating the mixture with illite [48,49]. The presence of the $\mathrm{Al}-\mathrm{OH}$ triplet and the slight inflection around $\sim 2165 \mathrm{~nm}$ allowed the identification of kaolinite in the spectra $\mathrm{d}$ and $\mathrm{j}$ (Figure 3) $[8,48,49,53]$. Figure 4 (1) shows a sharp absorption at $\sim 2312 \mathrm{~nm}$ and a shallow feature at $\sim 2390 \mathrm{~nm}$, indicating that another smectite group mineral may be present, probably saponite, with diagnostic $\mathrm{Mg}$ - $\mathrm{OH}$ features at $\sim 2310 \mathrm{~nm}$ and $\sim 2380 \mathrm{~nm}[48,49]$. The last three spectra of Figure 4 show distinct mineral assemblages. In spectra $\mathrm{r}$ and $\mathrm{s}$, besides the montmorillonite features (broad, asymmetric water absorptions), it was possible to identify: (i) a deep symmetric but broad main $\mathrm{Al}-\mathrm{OH}$ feature, (ii) two $\mathrm{OH}^{-}$absorptions located at $\sim 1574 \mathrm{~nm}$ and $\sim 1834 \mathrm{~nm}$, and (iii) a deep, broad, asymmetric $\mathrm{Mg}-\mathrm{OH}$ feature at $\sim 2355 \mathrm{~nm}$ that allowed the recognition of cookeite (Libearing chlorite) $[19,25,54,55]$. Spectrum $t$ (Figure 4 ) shows illite/white mica features: (i) the 
sharp and symmetric $\mathrm{OH}^{-}$and $\mathrm{Al}-\mathrm{OH}$ features at $\sim 1413 \mathrm{~nm}$ and $2198 \mathrm{~nm}$, respectively and (ii) the well-pronounced $\mathrm{Al}-\mathrm{OH}$ secondaries at $2345 \mathrm{~nm}$ and $2434 \mathrm{~nm}$ [47-49]. The water feature is deep and asymmetrical but shorter than the $\mathrm{Al}-\mathrm{OH}$, diagnosing the existence of illite [49]. Looking at the VNIR portion of the spectra, it was possible to notice a fall off to extreme blue in the reflectance curves (left panel of Figure 4), indicating that iron could be present in several samples [53]. Both ferric and ferrous iron were identified, the latter mainly through its characteristic ramp-like feature around $1150 \mathrm{~nm}$ [56]. Notwithstanding, similar features around $\sim 1150 \mathrm{~nm}$ were interpreted as water features in montmorillonite spectra by Hunt and Salisbury [47].
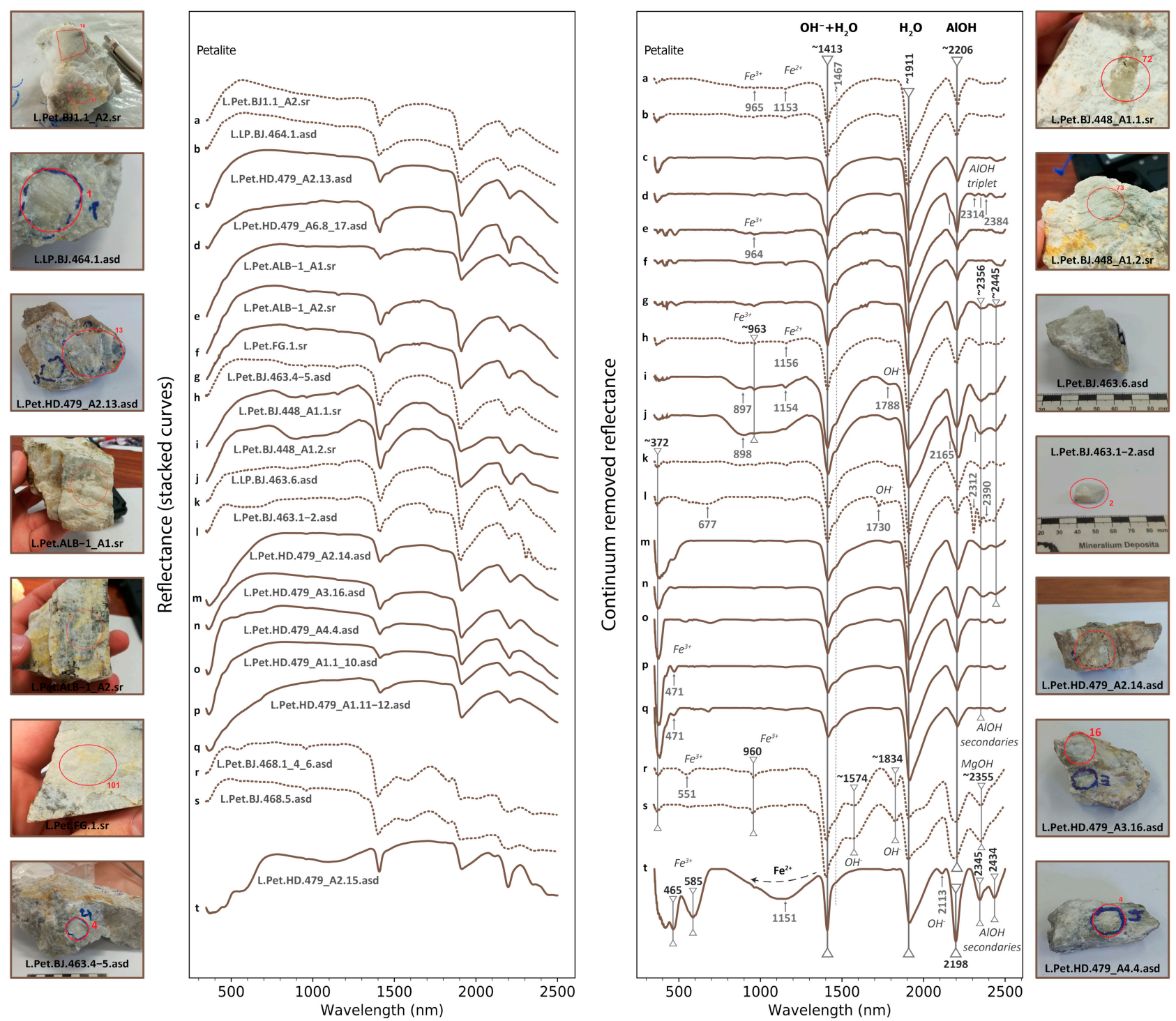

Figure 4. Spectral signature of petalite (a Li-bearing feldspathoid): reflectance curves (to the left) and continuum removed curves (to the right). The main absorption features are highlighted, and sample photographs are provided. Dotted curves: fresh samples; full curves: samples with visible signs of weathering. Each spectrum has a database code [45] providing information about the type of sample (L-Li-bearing minerals); mineralogy (Pet—petalite); sample provenance (ALBAlberto mine and BJ—Bajoca mine, FG—Fregeneda, and HD—Hinojosa de Duero); a three-digit numerical part representing the GPS code; a one- or two-digit code representing the spectra number or the averaged spectra numbers; and a reference to the spectroradiometer employed (sr-SR-6500; asd-FieldSpec 4).

Lastly, the position of the $\sim 2200 \mathrm{~nm} \mathrm{Al-OH}$ feature was evaluated for all Li-minerals (Figure A1, Appendix A) as a possible factor for mineral discrimination. 
Characterization of Petalite Alteration Products

The knowledge on the alteration associations can help to refine satellite image processing algorithms and to better understand the spectral behavior of fresh samples. During the field campaigns, it was possible to identify in the Bajoca mine front white to greenish clays preserving petalite cleavage (Figure 5a,b) [57] and yellow to greenish petalite crystals in Hinojosa de Duero. Additionally, in the Bajoca mine front, some petalite relics were found within the heavily altered portions, mainly consisted of friable clay-like minerals. Petalite relics and clayey alteration products were characterized through petrography, XRD, and reflectance spectroscopy. Table 1 summarizes these results and the ICP-OES Li quantification. Appendix A (Figure A6) provides the XRD diffractograms.

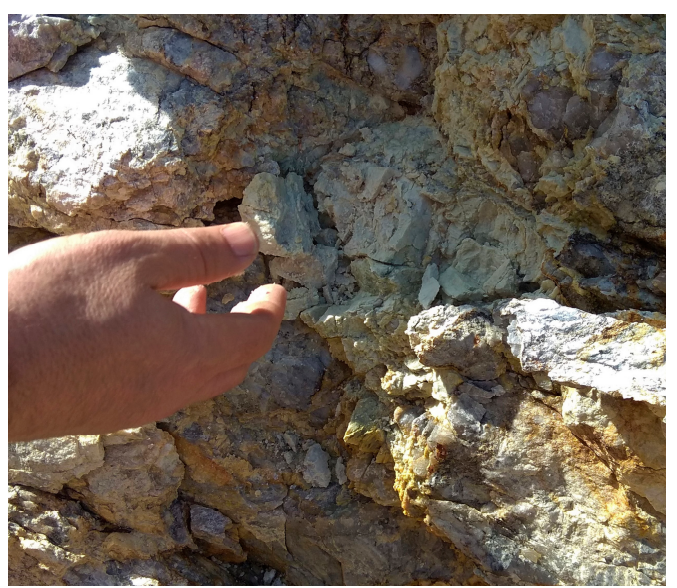

(a)

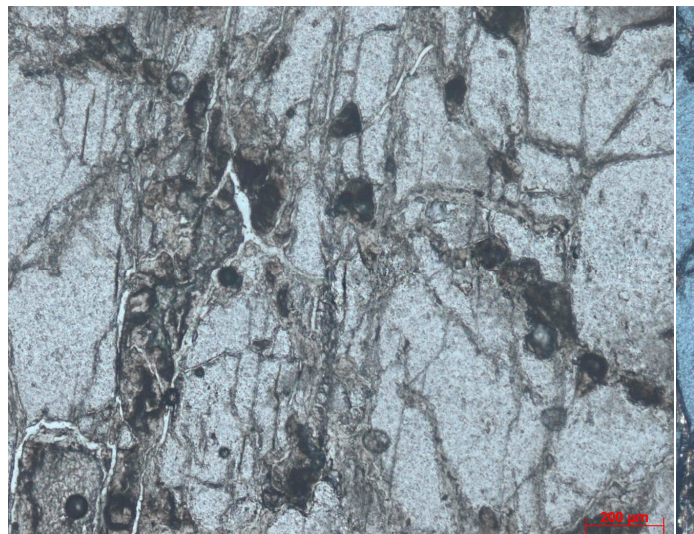

(c)

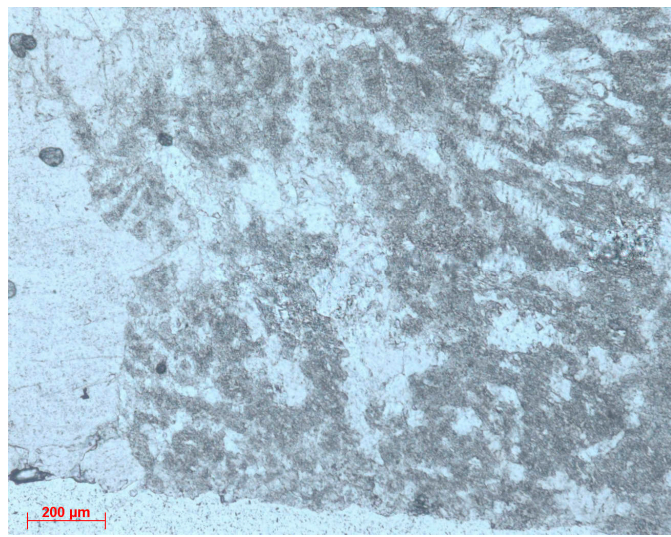

(e)

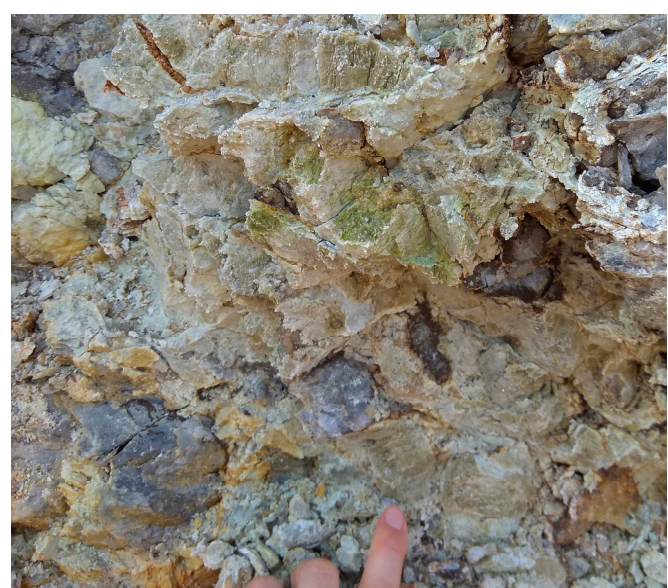

(b)

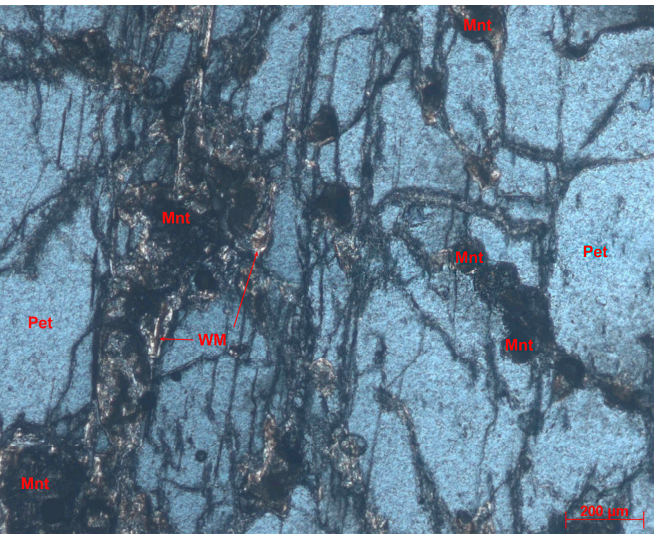

(d)

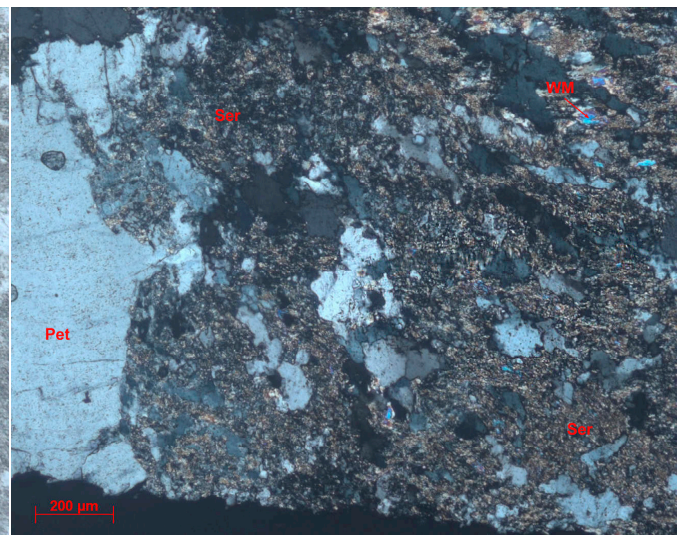

(f)

Figure 5. Cont. 


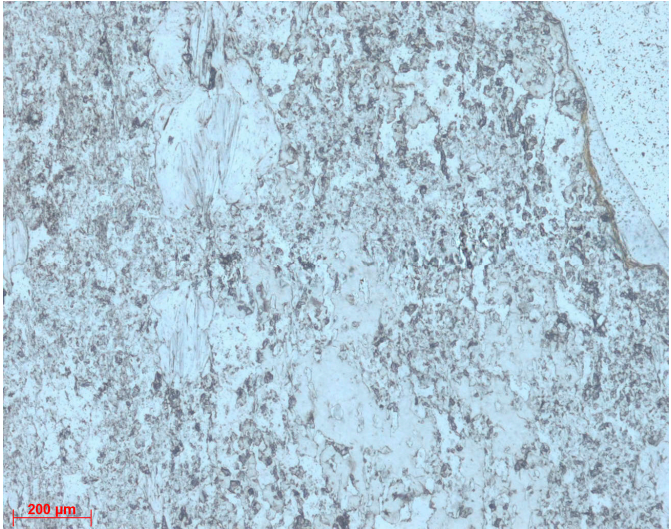

(g)

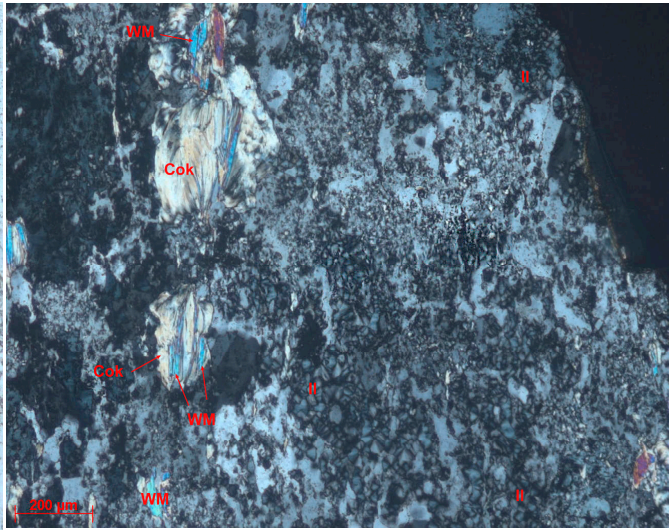

(h)

Figure 5. $(\mathbf{a}, \mathbf{b})$ Petalite altering to whitish and greenish clay minerals in the Bajoca mine front. (b) Former petalite crystal with preserved cleavage. (c,d) Photomicrographs of petalite relic with fractures filled by white mica and montmorillonite in parallel polarized light-ppl (c) and crosspolarized light $-\mathrm{cpl}(\mathbf{d})$. (e,f) Photomicrographs of petalite altering to sericite, white mica, and quartz in ppl and cpl, respectively. (g,h) Former petalite replaced by cookeite associated with white mica, surrounded by quartz and pseudospherulitic clays in ppl and cpl, respectively. Cok—cookeite (Li-chlorite); Mnt—montmorillonite; Pet—petalite; Ser—sericite; WM-white mica.

Table 1. Characterization and mineral identification of petalite's alteration products through petrography, XRD, and reflectance spectroscopy. Li quantification through ICP-OES is also shown. Alb-albite; Cok-cookeite (Li-chlorite); Il—illite; Kao-kaolinite; Mnt—montmorillonite; Msc—muscovite; Non—nontronite; Or—orthoclase; Pet—petalite; Pl— plagioclase; Qtz—quartz; Sap—saponite; Sep—sepiolite; Ser—sericite; WM—white mica. Sample provenance: BJ—Bajoca mine; HD—Hinojosa de Duero.

\begin{tabular}{|c|c|c|c|c|c|}
\hline Sample & Friability & Petrography & XRD & Spectroscopy & $\mathrm{Li}_{2} \mathrm{O}(\%)$ \\
\hline BJ.450 & Friable & - & Qtz, Il, Mnt/Non, Kao & Mnt & 0.116 \\
\hline BJ-20-12 & Friable & - & - & Mnt, Il/WM & 0.248 \\
\hline HD.479 & Hard rock & Pet, Ser, Pl, Qtz, WM & - & Mnt, Il/WM & 4.585 \\
\hline BJ2-01 & Friable & - & Qtz, Non, Msc, Il-Mnt & Mnt, Il/WM & 0.082 \\
\hline BJ2-02 & Friable & - & Qtz, Il/Sep, Msc, Or, Alb & Mnt, Il/WM & 0.099 \\
\hline BJ3-01 & Friable & - & Qtz, ll, Msc (phengitic), Alb & Mnt, Il/WM & 0.062 \\
\hline BJ.451 & Hard rock & Cok, WM, Ser, Qtz & - & Mnt, Kao, Sap & 0.409 \\
\hline BJ4-01 & Hard rock & Pet, Mnt *, WM, Pl & - & Mnt, Il/WM, Sap, Kao & 4.628 \\
\hline
\end{tabular}

${ }^{*}$ Identified through SEM-EDS.

Figure $5 c-h$ shows representative photomicrographs of petalite's alteration minerals. Thin sections of the less altered samples allowed identifying petalite in two out of the three. In the third, petalite is completely replaced despite preserving its cleavage, as previously described by Cardoso-Fernandes et al. [57]. Petalite alteration concentrates along the cleavage (Figure 5c,d), filled by fine white mica and pale brown clays (under parallel polarized light-ppl; Figure 5c), identified as montmorillonite through SEM-EDS [57]. Montmorillonite also forms spherical aggregates more or less aligned (Figure $5 \mathrm{c}, \mathrm{d}$ ). Local sericitization was observed on the crystal borders (Figure 5e,f). Figure 5g,h shows the formation of cookeite (associated with white mica) and clay minerals with pseudospherulitic habit, often interpreted as crystals growing filling pre-existing voids [58].

Regarding the spectral behavior of the alteration assemblages (Figure 6), montmorillonite features such as the broad, asymmetric $\mathrm{OH}^{-}(\sim 1413 \mathrm{~nm})$ and $\mathrm{H}_{2} \mathrm{O}(\sim 1912 \mathrm{~nm})$ absorptions with sharp minima, the Al-OH $(\sim 2200 \mathrm{~nm})$ feature, and the small inflection around $\sim 1467 \mathrm{~nm}[1,48,49]$ suggests its identification in spectra from a to $\mathrm{j}$. The X-ray diffraction technique identified montmorillonite only in two of the four analyzed samples (Table 1 and Appendix A, Figure A6). In spectra from b to h, illite and/or white 
mica are also detected by (i) the Al-OH secondaries at $\sim 2350 \mathrm{~nm}$ and $\sim 2440 \mathrm{~nm}$, (ii) the slight $\mathrm{OH}^{-}$feature at around $\sim 1790 \mathrm{~nm}$, and (iii) the proportion of Al-OH $(\sim 2200 \mathrm{~nm})$ absorption depth to water absorption depth ranging around 1/2 [47-49]. The coexistence of illite and white mica was confirmed three samples analyzed through XRD (Table 1 and Appendix A, Figure A6). In Figure 6, the spectra i-k represent more complex mineral assemblages. Kaolinite can be present in spectra $\mathrm{i}$ and $\mathrm{j}$ because of the Al$\mathrm{OH}$ absorption triplet $(\sim 2310 \mathrm{~nm}-\sim 2350 \mathrm{~nm}-\sim 2387 \mathrm{~nm})$ and the slight inflection around $\sim 2165 \mathrm{~nm}[8,48,49,53]$. Nonetheless, the deeper 2311-nm absorption in spectra $\mathrm{j}$ indicates that a magnesium-bearing mineral such as saponite or sepiolite is also present $[48,49]$. Oppositely, spectrum $\mathrm{k}$ of Figure 6 is dominated by illite and/or white mica features: (i) deep, sharp, and symmetric main Al-OH feature $(2196 \mathrm{~nm})$ associated with a sharp, symmetric $\mathrm{OH}^{-}$features $(1409 \mathrm{~nm}$ ); (ii) very pronounced $\mathrm{Al}-\mathrm{OH}$ secondaries (at $2350 \mathrm{~nm}$ and $2433 \mathrm{~nm}$ ); and (iii) minor $\mathrm{OH}^{-}$feature at $2105 \mathrm{~nm}$ [47-49]. Most of the spectra of Figure 6 show iron-related absorption features, as observed in petalite fresh samples (Figure 4). The wavelength position allowed the discrimination of both ferrous and ferric iron [56].
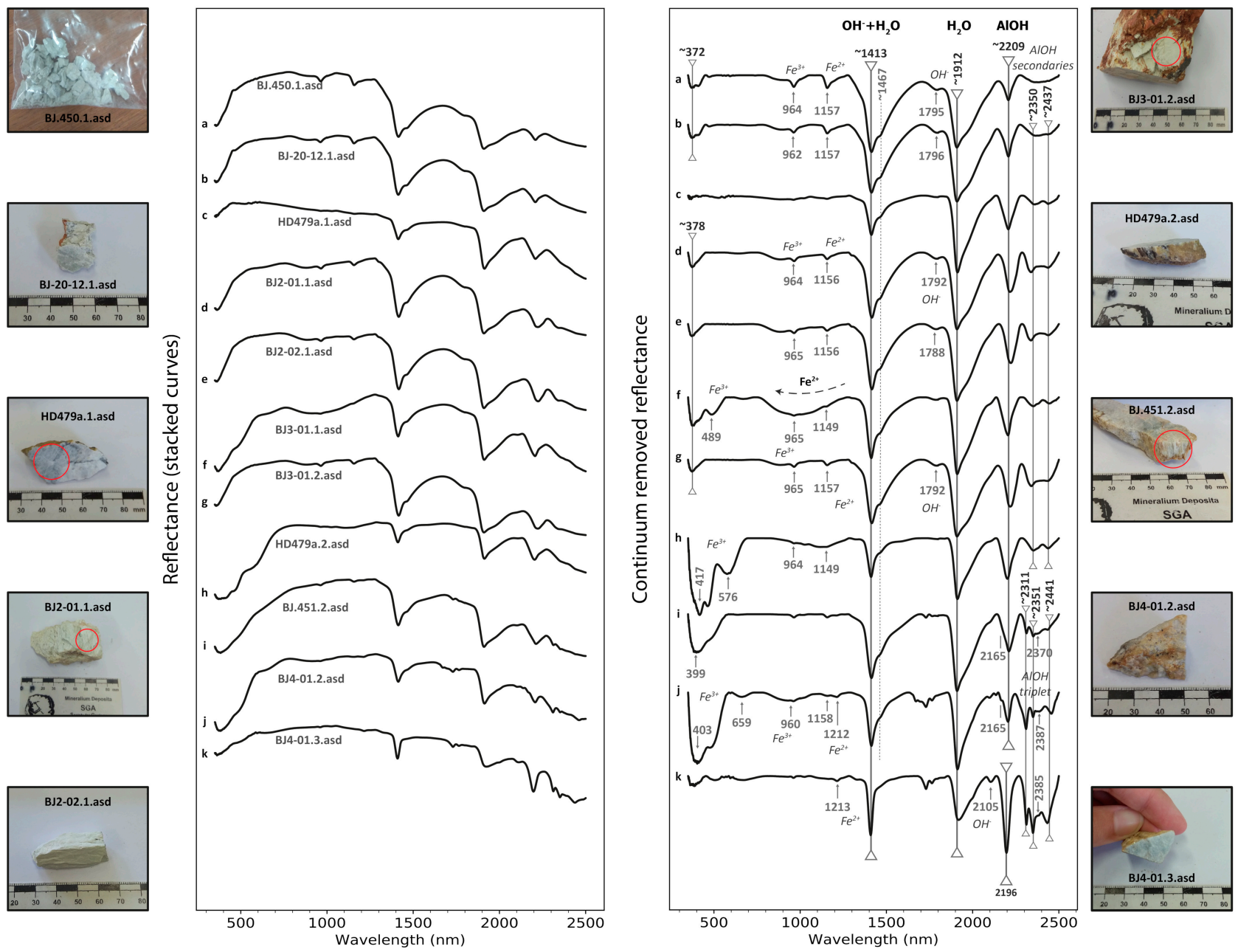

Figure 6. Spectral signature of the petalite's alteration products: reflectance curves (to the left) and continuum removed curves (to the right). The main absorption features are highlighted, and sample photographs are provided. Each spectrum name is composed by the sample provenance (BJ-Bajoca mine and HD-Hinojosa de Duero), a field code, a one-digit number representing the spectra, and the spectroradiometer employed (asd-FieldSpec 4).

As done for the spectra of Li-minerals, the position of the main Al-OH feature of the petalite alteration products was also assessed in Figure A1 (Appendix A). Additionally, any possible correlation between the $\mathrm{Li}$ content and the absorptions features in terms 
of wavelength, depth, area, and full-width at half maximum (FWHM) was evaluated (Figure 7).



(a)

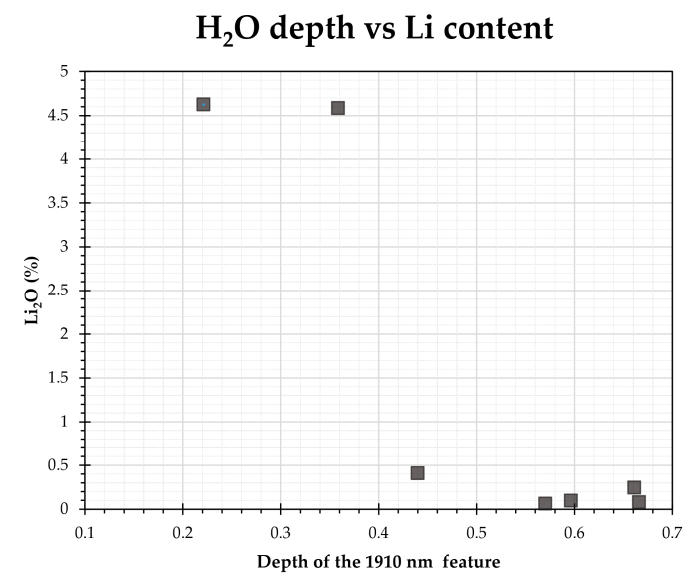

(b)

Figure 7. Relation between the depth of the hydroxyl (a) and water (b) absorption features and the Li content of the altered petalite samples.

\subsection{Spectral Studies for Lithological Classification}

This section concerns the comparison of the spectral behavior of the main field lithologies. Additionally, a description of the areas misclassified as Li-pegmatite is presented, as well as the spectral behavior of the samples collected in each of the four areas.

Stacked reflectance and continuum removed curves of the metasedimentary formations from the CXG are presented in Figure $8(\mathrm{a}-\mathrm{g})$. White mica diagnostic features such as (i) deepest, sharp Al-OH feature around $2214 \mathrm{~nm}$, (ii) sharp and symmetric $\mathrm{OH}^{-}$feature $(\sim 1413 \mathrm{~nm})$ associated with the absence of a water feature (expected around $\sim 1900 \mathrm{~nm}$ ), and (iii) weak to pronounced Al-OH secondaries at $\sim 2346 \mathrm{~nm}$ and $\sim 2451 \mathrm{~nm}$ dominate the spectra of Figure $8(a-c)$ [47-49]. The spectra of fresh samples $(a-c)$ are also characterized by a ramp-like absorption feature due to the presence of ferrous iron $\left(\mathrm{Fe}^{2+}\right)[56]$, together with the $\sim 750 \mathrm{~nm}, \sim 920 \mathrm{~nm}$, and $\sim 1150 \mathrm{~nm} \mathrm{Fe}^{3+}$ and $\mathrm{Fe}^{2+}$ features $[47,50,54]$. These VNIR absorptions, associated with a slight inflection around $\sim 2250 \mathrm{~nm}$, related to the $\mathrm{Fe}-\mathrm{OH}$ bonds [6,49] or $\mathrm{Al}(\mathrm{Mg}, \mathrm{Fe})-\mathrm{OH}$ bonds [59,60], and a slightly deeper 2350-nm absorption when comparing with the $\sim 2451 \mathrm{~nm}$ Al-OH secondary, indicating the contribution of the $\mathrm{Mg}-\mathrm{OH}$ bonds [48,49], are indicative of the presence of chlorite in fresh samples $[47,49,54,59]$. Despite the absorption features of spectra $d-f$ of Figure 8 not being evident, there is (i) a weak, broad, rounded water absorption at $\sim 1926 \mathrm{~nm}$ that may be associated with fluid inclusions in quartz [49] and (ii) ferric iron-related $\left(\mathrm{Fe}^{3+}\right)$ absorptions around $\sim 942 \mathrm{~nm}$ evidencing sample oxidation (Figure 8) [49,56]. Finally, spectra g shows the calcite diagnostic features-namely, the carbonate ion $\left(\mathrm{CO}_{3}{ }^{2-}\right)$ feature at $2339 \mathrm{~nm}$ and weaker carbonate features around 1900-2000 nm [49].

Regarding the granite samples, continuum removed curves (Figure $8(\mathrm{~h}-\mathrm{k})$ ), evidence a mixture of montmorillonite/illite and white mica features: (i) asymmetric $\mathrm{OH}-(\sim 1413 \mathrm{~nm})$ and water $(\sim 1913 \mathrm{~nm})$ features, (ii) broad water feature with sharp minima and similar depth to the $\mathrm{Al}-\mathrm{OH}$ one $(\sim 2206 \mathrm{~nm})$, (iii) a small inflection around $\sim 1467 \mathrm{~nm}[1,48,49]$, (iv) Al-OH secondaries at $\sim 2351 \mathrm{~nm}$ and $\sim 2443 \mathrm{~nm}$, and (v) weaker $\mathrm{OH}-$ absorption at $\sim 2110 \mathrm{~nm}$ [47-49]. Fresher samples (spectra h-i) show distinctive VNIR features at $\sim 960 \mathrm{~nm}$ $\left(\mathrm{Fe}^{3+}\right)$ and $\sim 1150 \mathrm{~nm}\left(\mathrm{Fe}^{2+}\right)$, inferring the presence of biotite. Despite the dominance of montmorillonite and white mica feature, which overlap with the main kandite group absorption features, altered samples (spectra j-k) show slight inflections at $\sim 2165 \mathrm{~nm}$ and $\sim 2382 \mathrm{~nm}$ that indicate that a kandite group mineral, like kaolinite or halloysite, is present in the mineral mixture $[8,49]$. Additionally, goethite was identified in altered samples 
through its diagnostic ferric iron features at $\sim 670 \mathrm{~nm}$ and $\sim 950 \mathrm{~nm}$ and peak in the red region $(\sim 750 \mathrm{~nm})[49,56]$.
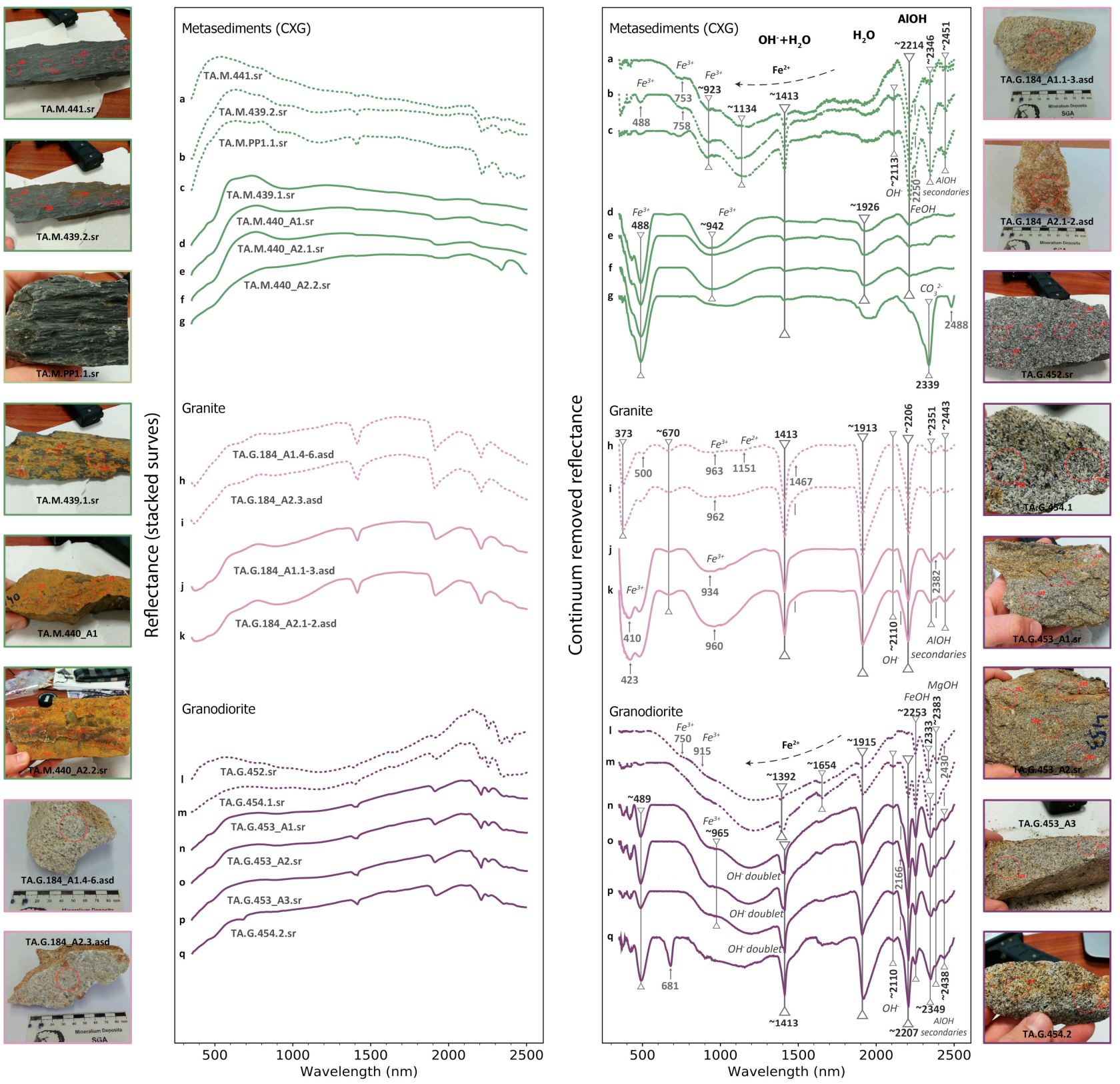

Figure 8. Spectral signature of the outcropping lithologies: reflectance curves (to the left) and continuum removed curves (to the right). The main absorption features are highlighted, and sample photographs are provided. Dotted curves: fresh samples; full curves: samples with visible signs of weathering. Each spectrum has a database code [45] providing information about the type of sample (TA—training areas), type of lithology (M-CXG metasediments, G-granite and granodiorite), a three-digit numerical part representing the GPS code, a one- or two-digit code representing the spectra number or the averaged spectra numbers, and a reference to the spectroradiometer employed (sr-SR-6500; asd—FieldSpec 4).

The granodiorite samples stacked reflectance and continuum removed curves are displayed in Figure 8 (l-q). White mica features dominate the spectra $n$ to $q$, as evidenced by (i) the deep, narrow Al-OH absorption at $2207 \mathrm{~nm}$, (ii) the associated Al-OH secondaries (at $\sim 2349 \mathrm{~nm}$ and $\sim 2438 \mathrm{~nm}$ ), and (iii) minor $\mathrm{OH}^{-}$combined with lattice modes absorption features around $\sim 2110 \mathrm{~nm}$ [47-49]. White mica is also present in Figure $8(\mathrm{~m})$. The ubiquitous biotite presence in all spectra ( 1 to q) was confirmed by its diagnostic (i) 2253-nm absorption feature, related to the either $\mathrm{Fe}-\mathrm{OH}$ bonds [6,49] or $\mathrm{Al}(\mathrm{Mg}, \mathrm{Fe})-\mathrm{OH}$ 
bonds [59,60] and (ii) $\mathrm{Mg}-\mathrm{OH}$ absorptions at $2330-2350 \mathrm{~nm}$ and $2380 \mathrm{~nm}[48,49]$. The higher relative depth of the $\mathrm{Mg}-\mathrm{OH}$ feature compared to the $\sim 2250-\mathrm{nm}$ absorption and the slight inflection/weak absorption around $2430 \mathrm{~nm}$ indicate that biotite is Mg-rich (possibly mixed with phlogopite-for example, spectra q) [49,53]. Biotite also occurs mixed with chlorite in spectrum 1, being chlorite identified through its diagnostic VNIR features ( 750-nm, $\sim 915-\mathrm{nm}$, and 1150-nm ferric and ferrous iron absorptions) $[47,50,54,56]$. The existence of a doublet $\mathrm{OH}^{-}$absorption in spectra o to $\mathrm{q}$, associated with the slight inflection at $\sim 2166 \mathrm{~nm}$ and the $\mathrm{Al}-\mathrm{OH}$ absorptions at $\sim 2349 \mathrm{~nm}$ and $\sim 2383 \mathrm{~nm}$ is characteristic of the kandite group $[8,48,49,53]$. The prominent and deep water feature $(\sim 1915 \mathrm{~nm})$ is diagnostic of halloysite [48,49]. Lastly, spectra q of Figure 8 shows a broad, asymmetric water feature that coupled with a unique $\mathrm{OH}^{-}$feature (at $~ 1413 \mathrm{~nm}$ ), and an $\mathrm{Al}-\mathrm{OH}$ feature (at $\sim 2207 \mathrm{~nm}$ ) indicates that montmorillonite and/or illite may be present $[48,49]$.

Finally, the Li-bearing pegmatites were separated according to the dominant mineralogy into (i) lepidolite-bearing and (ii) petalite-bearing. Stacked reflectance and continuum removed curves of both lepidolite- and petalite-bearing pegmatites are presented in Figure 9.

As shown in Figure 9 (a-f), white mica related absorptions dominate all spectra from lepidolite-bearing pegmatites (sharp and symmetric main $\mathrm{OH}^{-}$and $\mathrm{Al}-\mathrm{OH}$, coupled with the associated secondaries at $\sim 2347 \mathrm{~nm}$ and $\sim 2434 \mathrm{~nm}$ and weaker $\mathrm{OH}^{-}$combined with lattice modes absorptions at $1835 \mathrm{~nm}, \sim 1997 \mathrm{~nm}$, and $2116 \mathrm{~nm}$ [47-49]). However, features in the VNIR region such as (i) the $\sim 551-\mathrm{nm}$ absorption, associated with the incorporation of $\mathrm{Fe}^{3+}$ and/or $\mathrm{Mn}^{3+}$, and (ii) the peak in the red region (left panel of Figure 9), allowed discrimination of the white mica as lepidolite in spectra $\mathrm{c}-\mathrm{f}$ [50]. In the VNIR region, another iron-related feature was observed at $\sim 960 \mathrm{~nm}\left(\mathrm{Fe}^{3+}\right)$ [56]. Some clay minerals, such as montmorillonite and illite, may be present in spectra a, d, and $\mathrm{f}$ (Figure 9), identified by the relatively deep and/or asymmetric of the water feature at $\sim 1912 \mathrm{~nm}$ and the slight inflection around $1467 \mathrm{~nm}[1,49]$.

Like the petalite samples, mixtures of montmorillonite and illite dominate most of the spectra of the petalite-bearing pegmatites (Figure $9(\mathrm{~g}, \mathrm{~h}, \mathrm{j}-\mathrm{q})$ ). The montmorilloniterelated inflection at $\sim 1467 \mathrm{~nm}$ is present in all the mentioned spectra [1]. In spectra g, $i$ and $j$, montmorillonite features prevail over illite features: (i) higher asymmetry of the main $\mathrm{OH}^{-}$feature $(\sim 1410 \mathrm{~nm})$, (ii) higher depth of the water feature $(\sim 1912 \mathrm{~nm})$ in comparison with the main Al-OH absorption (2192-2208 nm), and (iii) Al-OH secondaries $(\sim 2349 \mathrm{~nm}$ and $\sim 2439 \mathrm{~nm})$ absent or poorly developed [48,49]. In spectra o-q, the opposite happens, with illite being predominant due to: (i) narrower and/or more symmetric main $\mathrm{OH}^{-}$feature, (ii) weaker $\mathrm{OH}^{-}$absorptions $1620 \mathrm{~nm}$ and $2108 \mathrm{~nm}$, (iii) higher depth of the main $\mathrm{Al}-\mathrm{OH}$ feature in relation to the water one, and (iv) well-developed $\mathrm{Al}-\mathrm{OH}$ secondaries $[48,49]$. Spectra $k-n$ represent a mixture of montmorillonite and illite. The rounded water absorption in spectra $\mathrm{h}$ indicates that free water is present, which could be due to fluid inclusions in minerals such as quartz [49]. White mica, which is discriminated from illite by the absence of a water feature [49], predominates spectra $r-t$, although the white mica present in spectra $r$ is a hydrated white mica, probably sericite because the depth of the water feature is small than what would be expected for illite [49]. Figure 9 (w) shows diagnostic cookeite features, namely: (i) a broad, symmetric main Al-OH feature, (ii) $\mathrm{OH}^{-}$absorptions at $\sim 1581 \mathrm{~nm}$ and $\sim 1835 \mathrm{~nm}$, and (iii) a deep and broad $\mathrm{Mg}-\mathrm{OH}$ feature at $2358 \mathrm{~nm}[19,25,54,55]$. Cookeite also occurs mixed with white mica features in spectra $t$ and mixed with montmorillonite/illite in spectra q. Kaolinite was identified in Figure $9(\mathrm{~g}, \mathrm{j})$ through its characteristic Al-OH triplet and slight inflection at $\sim 2166 \mathrm{~nm}[8,48,49,53]$. Figure $9(\mathrm{u}, \mathrm{v})$ shows spectral behavior correspondent to orthoclase, where the absorptions at $\sim 1410 \mathrm{~nm}$ and $\sim 1912 \mathrm{~nm}$ may be the result of aqueous fluid inclusions $[47,55]$. Additionally, the $\sim 2110-\mathrm{nm}$ feature is diagnostic of ammonium $\left(\mathrm{NH}_{4}{ }^{+}\right)$, but its relatively shallow depth can indicate only small amounts of $\mathrm{NH}_{4}{ }^{+}$substituting $\mathrm{K}^{+}$ and not the $\mathrm{NH}_{4}{ }^{+}$feldspar (buddingtonite) $[49,61,62]$. When looking at the VNIR range, especially in the raw reflectance curves (left panel of Figure 9), goethite was identified in 
spectra $\mathrm{g}, \mathrm{h}, \mathrm{l}$, and $\mathrm{r}$, through its diagnostic ferric iron absorptions $\left(\mathrm{Fe}^{3+}\right)$ at $\sim 960 \mathrm{~nm}$ and $\sim 660 \mathrm{~nm}$ and peak in the red region around $\sim 760[49,56]$. Other iron-related features were also observed.
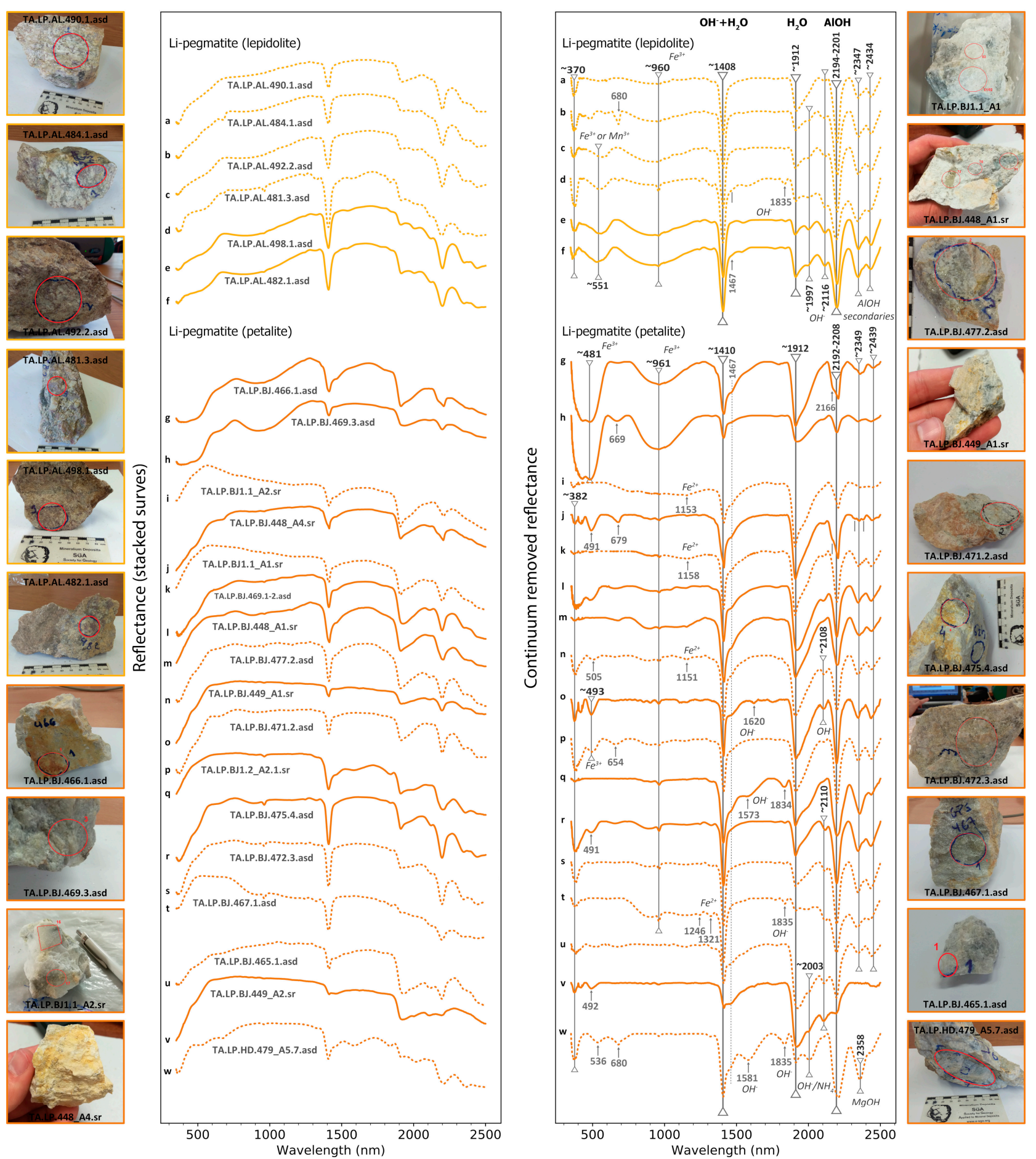

Figure 9. Spectral signature of the outcropping lithologies, namely lepidolite-bearing pegmatite and petalite-bearing pegmatite: reflectance curves (to the left) and continuum removed curves (to the right). The main absorption features are highlighted, and sample photographs are provided. Dotted curves: fresh samples; full curves: samples with visible signs of weathering. Each spectrum has a database code [45] providing information about the type of sample (TA-training areas); type of lithology (LP—Li-pegmatite); sample provenance (AL_Almendra, BJ—Bajoca mine, and HD—Hinojosa de Duero); a three-digit numerical part representing the GPS code; a one- or two-digit code representing the spectra number or the averaged spectra numbers; and a reference to the spectroradiometer employed (sr-SR-6500; asd—FieldSpec 4). 
Overall, the misclassified regions correspond to (i) wine or olive plantations, where the agricultural activities exposed metasedimentary boulders, or (ii) hillside and slope areas, where many rock boulders are naturally exposed. Petrography and reflectance spectroscopy studies were conducted to fully characterize the collected samples and understand if there can be any spectral confusion with the target class (Li-pegmatite) and minerals. The results are summarized in Table A1 (Appendix A), while the spectral curves and photomicrographs are presented in Figures A2 and A3, respectively.

As seen in Table A1, most of the samples correspond to CXG metasediments, although some quartzite and pegmatite samples were in some false-positive areas. The microscopic studies of CXG samples allowed characterization as interbed phyllites with metagraywacke layers, with well-preserved sedimentary features such as bedding and load casts (Figure A3a,b). The mineralogical assemblage identified, composed of quartz, white mica (detrital and metamorphic origin), biotite, chlorite, plagioclase, K-feldspar, detrital zircon, tourmaline, apatite, iron oxides, and other opaque minerals (Figure A3), is in line with the described in the literature [63]. Quartzite samples have tiny mica crystals in the matrix and exhibit an inherited clastic texture, compatible with the metapsamites described for the São Grabiel's Ordovician formation [37]. Lastly, no signs of Li mineralization were found in the pegmatite samples, which characterizes it as a barren pegmatite.

Figure A2 (Appendix A) shows the spectral signature of samples collected in falsepositive sites. The continuum removed curves related to the area no. 1 (Figure A2 (a-e)) reveal white mica in spectra c (sharp, symmetric main $\mathrm{OH}^{-}$and $\mathrm{Al}-\mathrm{OH}$ absorptions at $\sim 1414 \mathrm{~nm}$ and $\sim 2210 \mathrm{~nm}$, coupled with the Al-OH secondaries at $2350 \mathrm{~nm}$ and $\sim 2438 \mathrm{~nm}$ and the absence of water absorption). Illite was recognized in spectra $b$ through similar features but with its typical more profound water feature ( 1925 nm) [47-49]. In Figure A2 (e), montmorillonite deep water absorption is spectrally mixed with $\mathrm{Mg}-\mathrm{OH}$-related features at $\sim 2350 \mathrm{~nm}$ and $\sim 2383 \mathrm{~nm}$ (slight inflection), possibly due to the presence of chlorite or biotite (the VNIR features are not clear enough to discriminate the magnesium-bearing mineral) $[48,49,54]$. The wavelength position and rounded aspect of the water feature indicate the presence of free water, possibly related to fluid inclusions in quartz or the presence of iron oxides/hydroxides [49]. The ferric iron features at $\sim 680 \mathrm{~nm}$ and $\sim 960 \mathrm{~nm}$ and peak in the red region $(\sim 760 \mathrm{~nm})$ allowed identifying the goethite in spectra a, while the remaining VNIR absorptions indicate that other iron oxides/hydroxides are present in spectra b, d, and e of Figure A2 [49,56].

In the case of the false-positive area no. 2 (Figure A2 (f,g)), it was possible to recognize hydrated kaolinite or kaosmectite due to the (i) slight inflections $1407 \mathrm{~nm}$ and $\sim 2197 \mathrm{~nm}$ indicative of the $\mathrm{OH}^{-}$and Al-OH doublets; (ii) very shallow Al-OH triplet at $(\sim 2313 \mathrm{~nm}$, $\sim 2349 \mathrm{~nm}$, and $\sim 2384 \mathrm{~nm}$ ); and (iii) the deep water feature at $1921 \mathrm{~nm}[8,48,49,53]$. Spectra $\mathrm{g}$ of Figure A2 is dominated by illite features, although there is a slight inflection at a wavelength characteristic of the $\mathrm{Mg}-\mathrm{OH}$ bond (2379 nm) [47-49]. Identical $\mathrm{OH}^{-}$and $\mathrm{Al}-\mathrm{OH}$ features but with less profound water feature allowed to identify white mica in spectra $\mathrm{h}$ [47-49], while the rounded water feature has indicated the presence of quartz with fluid inclusions [49]. The remaining spectra (f and g) also show a distinctive wavelength position and roundness of the water feature, indicating free water. Based on the VNIR features, goethite was identified in Figure A2 $(f, g)$, while spectra h also shows some ferric iron absorptions $[49,56]$.

Regarding the spectra of the false-positive area no. 3 (Figure A2 (i-m)), the similar depth of the water $(\sim 1914 \mathrm{~nm})$ and main Al-OH $(\sim 2208 \mathrm{~nm})$ features indicate the spectral mixture montmorillonite ( 1465-nm inflection and broad, deep, asymmetric water feature with sharp minima) and illite (typical Al-OH secondaries) in spectra i and $\mathrm{k}[1,48,49]$. Montmorillonite also occurs mixed with chlorite/biotite in spectra $\mathrm{j}$ (well-pronounced $\mathrm{Fe}-\mathrm{OH}$ or $\mathrm{Al}(\mathrm{Mg}, \mathrm{Fe})-\mathrm{OH}$ absorption at $2254 \mathrm{~nm}$, associated with the deep $\mathrm{Mg}-\mathrm{OH}$ absorption at $\sim 2348 \mathrm{~nm}$ ), but the VNIR features are not clear enough to discriminate the two minerals $[6,48,49,59,60]$. Figure A2 (1) shows a predominance of montmorillonite features (absence of Al-OH secondaries, inflection at $1467 \mathrm{~nm}$, and deep water feature), 
but the shape of the 1914-nm (water) feature is not typical of the smectite group, with the rounded minima indicating the presence of free water $[1,48,49]$. Spectra $\mathrm{m}$ is dominated by chlorite features (diagnostic VNIR absorptions, inflection at $2000 \mathrm{~nm}$, and $\mathrm{Mg}-\mathrm{OH}-$ related absorption at $2348 \mathrm{~nm}$ ) [47-49,54,59] mixed with either white mica or illite [47-49]. Looking at the VNIR features in both reflectance and continuum removed curves, goethite can be present in spectra i, while other iron oxides and/or hydroxides (that not goethite or hematite) are present in spectra $j-1[49,56]$.

Finally, in the false-positive area no. 4 (Figure A2 $(n-q)$ ), white mica (sharp, symmetric $\mathrm{OH}^{-}$and $\mathrm{Al}-\mathrm{OH}$ features, associated with the $\mathrm{Al}-\mathrm{OH}$ secondaries and the absence of a prominent water feature), is mixed with chlorite (diagnostic VNIR absorptions and 2000-nm inflection) in spectra $\mathrm{n}$ and $\mathrm{q}[47-49,54,59]$. Spectra o and p show white mica features but a more pronounced, asymmetric water feature at $\sim 1914 \mathrm{~nm}$, indicating probable sericite (water absorption deeper than typical muscovite but not deep enough as illite) [49]. Ferric iron-related absorptions occur in spectra o and p of Figure A2.

The reflectance magnitude of the different classes is compared in Figure 10. Additionally, the minimum, maximum, and mean reflectance of each class are also compared in Figure A4 (Appendix A).

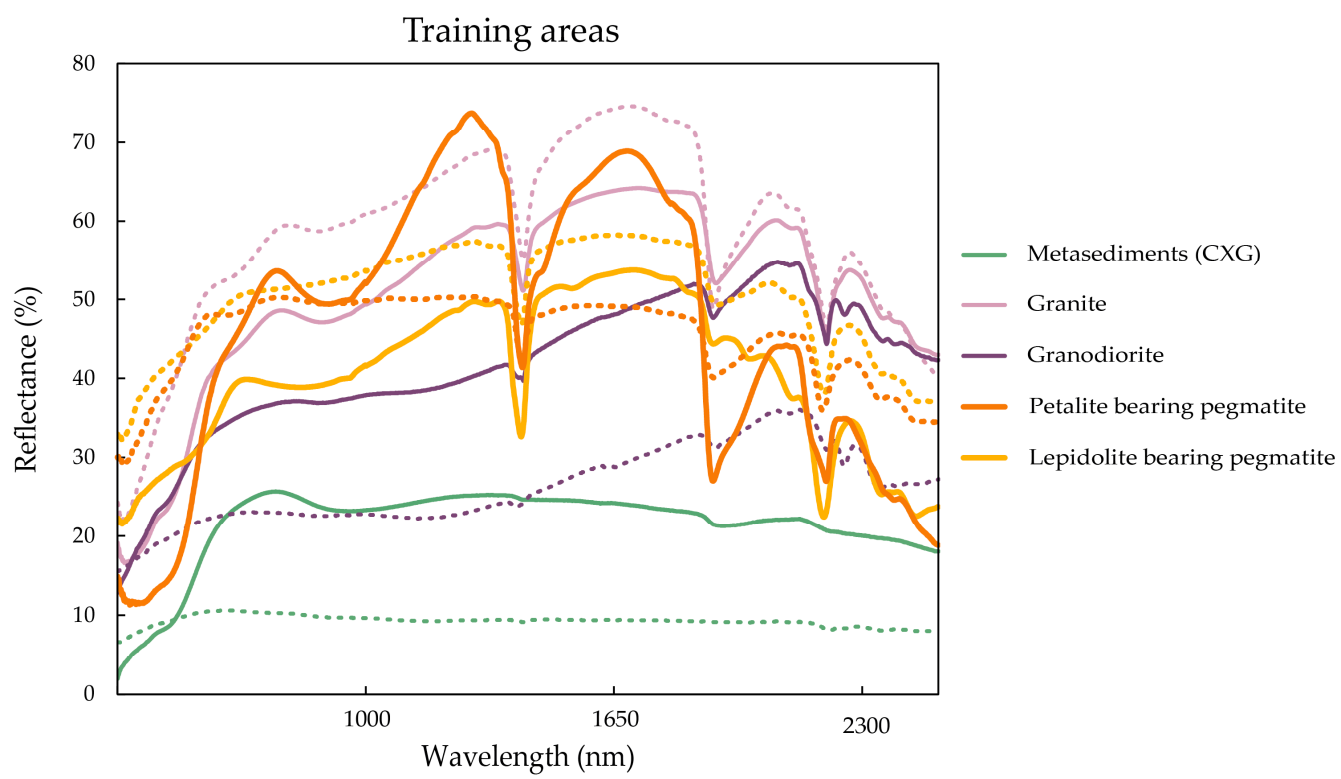

Figure 10. Comparison of the maximum reflectance magnitude of the different lithologies sampled at training area locations. Weathered samples (full lines) are discriminated from fresher samples (dotted lines).

Additionally, the wavelength position and depth of absorption features are among the most common criteria for lithological discrimination. Figure 11a shows the distribution of the wavelength of the main $\mathrm{Al}-\mathrm{OH}$ feature according to the distinct types of samples containing white mica, and Figure $11 \mathrm{~b}$ relates the position and depth of their $\mathrm{Al}-\mathrm{OH}$ feature. To better discriminate the CXG metasediments from the granitoids based on the spectral mineralogy, the chlorite and/or biotite composition was evaluated through the $\mathrm{Mg}-\mathrm{OH}$ wavelength position (Figure A5, Appendix A). Only the $\mathrm{Mg}-\mathrm{OH}$ absorption was used, because not all spectra presented the $\sim 2250$-nm feature well-defined.

Lastly, the spectral resolutions of different satellite or drone-borne sensors (such as Sentinel-2, Landsat-8 Operational Land Imager (OLI), Advanced Spaceborne Thermal Emission and Reflection Radiometer (ASTER), Prototype Research Instruments and Space Mission technology Advancement (PRISMA), and HySpex Mjolnir) were considered to evaluate the potential use of remote sensing data in Li-pegmatite exploration (Figure 12). 


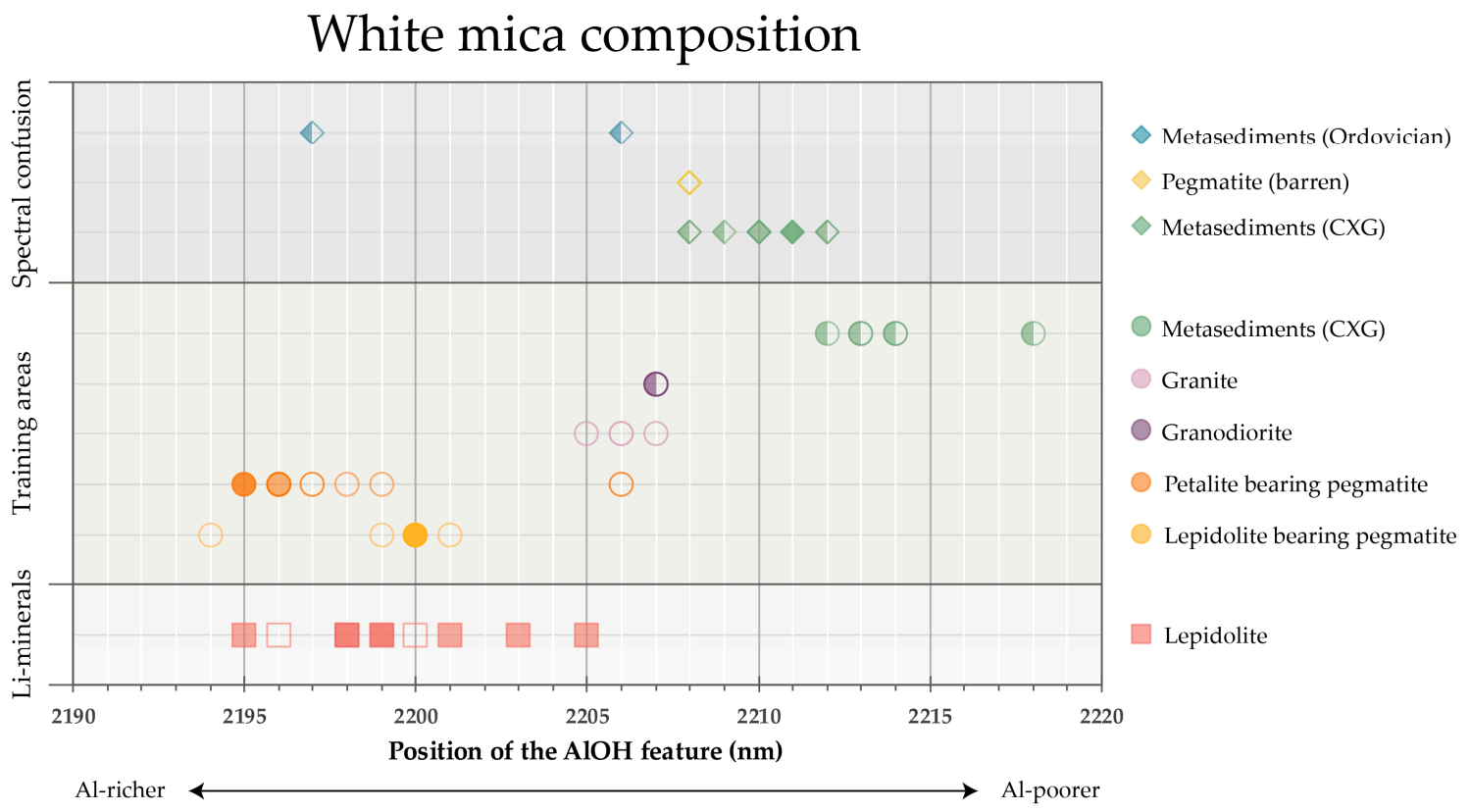

(a)



(b)

Figure 11. Wavelength position of the $\mathrm{Al}-\mathrm{OH}$ feature in samples containing white mica: (a) relation between the wavelength and white mica composition (based on References $[49,64]$ ) and (b) relation between depth and position of the Al-OH feature. Lepidolite samples (squares) were plotted for comparison. Circles correspond to samples from training areas, while diamonds represent false-positive areas. Full symbols correspond to samples where white mica was exclusively identified; half-full symbols correspond to mixtures of white mica with minerals that do not overlap the main Al-OH absorption; symbols without fill represent spectra where white mica occurs mixed with minerals whose feature overlaps the Al-OH absorption. 


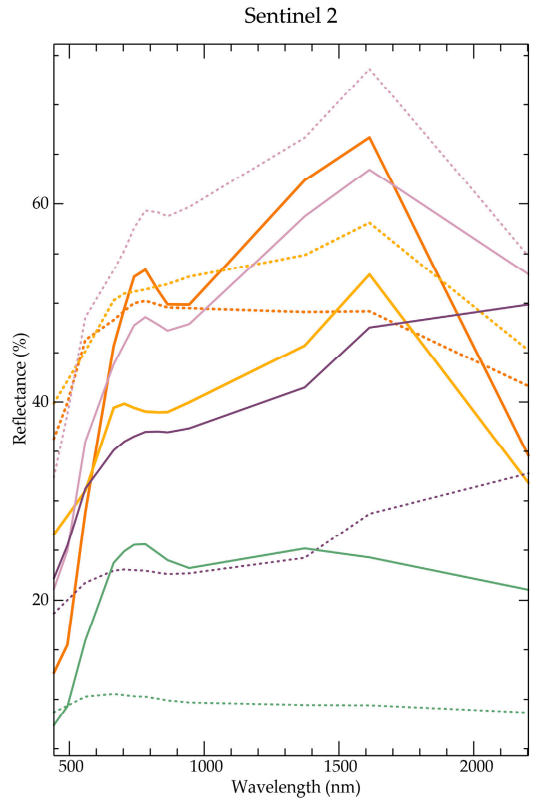

(a)

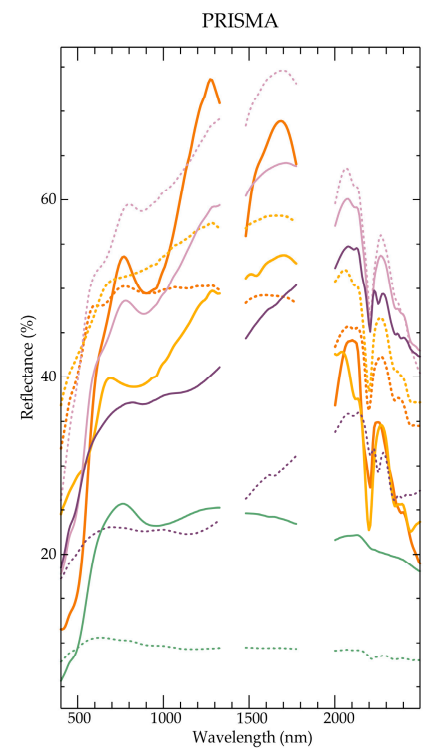

(d)

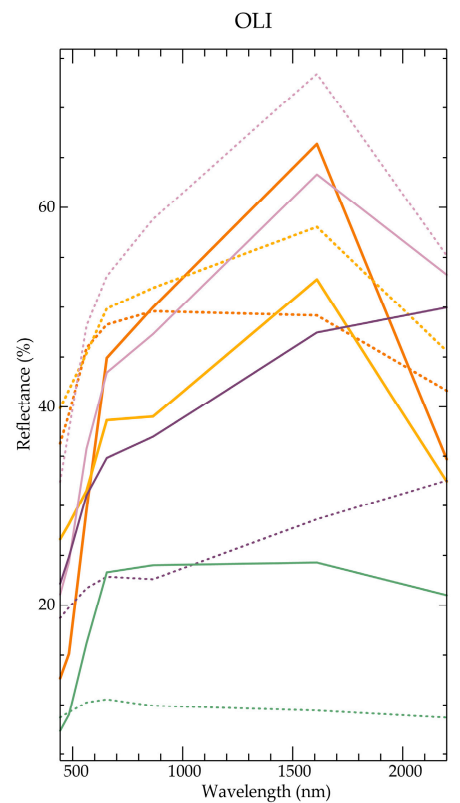

(b)

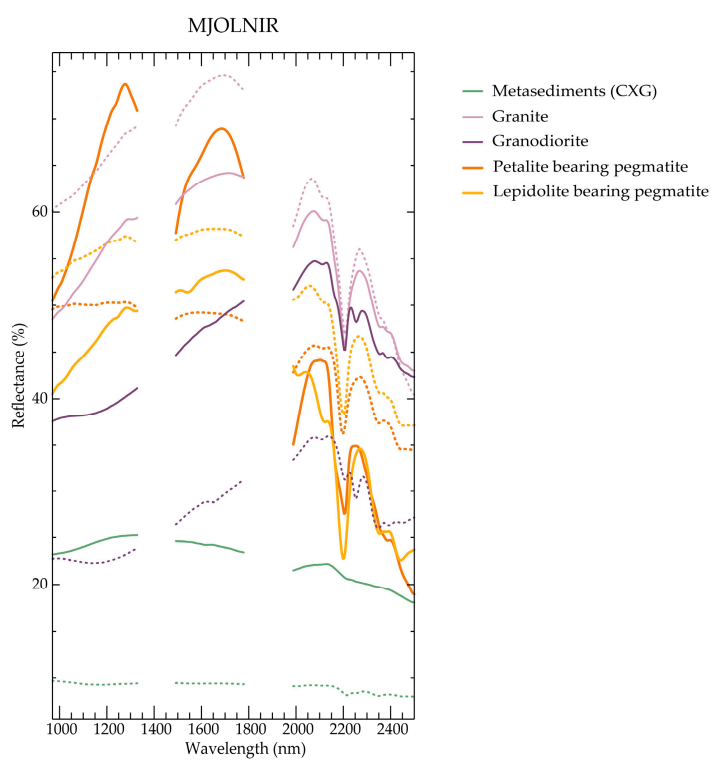

(e)

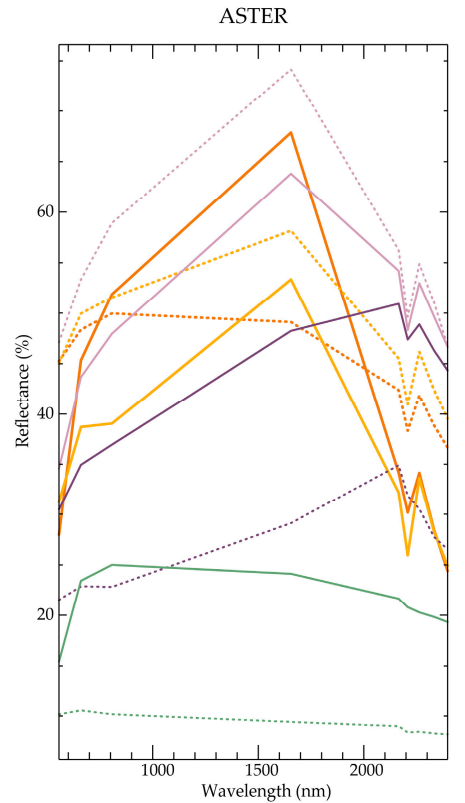

(c)

Figure 12. Laboratory spectra of representative spectra from the different training area lithologies (Figure 10) resampled to various multi- and hyperspectral sensors: (a) Sentinel-2, (b) Landsat-8 Operational Land Imager (OLI), (c) Advanced Spaceborne Thermal Emission and Reflection Radiometer (ASTER), (d) Prototype Research Instruments and Space Mission technology Advancement (PRISMA), and (e) Mjolnir. Weathered samples (full lines) are discriminated from fresher samples (dotted lines).

\section{Discussion}

\subsection{Spectral Behavior of Li-Bearing Minerals}

The collected lepidolite (Figure 2), spodumene (Figure 3), and petalite (Figure 4) spectra were compared, and, despite all three minerals showing significant absorption features in the same wavelength regions, the shape, symmetry, and relative depth of the features allowed differentiation of lepidolite from the remaining two Li-minerals. This is because lepidolite has diagnostic absorption features at around $550 \mathrm{~nm}$ and $960 \mathrm{~nm}$, as well as a drop-off of the extreme blue (which reflect the purple color of lepidolite) and the white mica typical features due to the hydroxide ion $\left(\mathrm{OH}^{-}\right)$absorption around $\sim 1409 \mathrm{~nm}$ associated with the principal, sharp Al-OH absorption feature (between $2195 \mathrm{~nm}$ and 
$2205 \mathrm{~nm}$ ) and the Al-OH secondaries (around $2348 \mathrm{~nm}$ and $\sim 2435 \mathrm{~nm}$, respectively). These VNIR absorption features allow discriminating lepidolite from other white micas [50]. Since hyperspectral and multispectral air- or satellite-borne sensors cover the VNIR wavelength region, there is a high potential for lepidolite identification using remote sensing data. Previous studies where lepidolite was recognized and discriminated from other white micas using airborne HyMap hyperspectral data $[65,66]$ corroborate this statement, although the position of the Al-OH features also played a fundamental part in that discrimination [66] (this topic will be further discussed below). All three Li-minerals show diagnostic ironrelated features in the VNIR region, probably due, in part, to the substitution of aluminum in the minerals' structures (e.g., References [50,67]). In spodumene, iron substitution is observed, as well in the SWIR region ( 2240 $\mathrm{nm})$.

Concerning the petalite and spodumene, it was not possible to identify any diagnostic feature because the alteration minerals (montmorillonite with minor illite and kaolinite) dominate their spectral curves. Though, spodumene presents iron-related absorptions at 2240 nm not visible in petalite. Conversely, some petalite samples showed additional cookeite (Li-chlorite) and saponite (Mg-smectite) features not recognized in spodumene samples. However, this is not enough to distinguish between the two Li-aluminosilicates, because cookeite and other clay minerals (such as kaolinite or smectites) can form from either petalite or spodumene alteration (e.g., [68-70] and references therein). These results also indicate that it would not be possible to spectrally discriminate spodumene or petalite from montmorillonite/illite, based on the absorption features.

Moreover, several authors have noticed a shift in the wavelength position of the main $\mathrm{Al}-\mathrm{OH}$ absorption due to different $\mathrm{Al}$ contents in white micas [7,49,52,64]. As it can be seen in Figure A1 (Appendix A), the lepidolite samples show the Al-OH feature at shorter wavelengths ( $\leq 2005 \mathrm{~nm}$ ), which indicates a higher Al content $[7,49,64]$. Although the $\mathrm{Al}-\mathrm{OH}$ feature position of spodumene and petalite overlaps the lepidolite range, there is a tendency for the Al-OH feature to be located at longer wavelengths (Figure A1). These wavelength differences could be caused by the spodumene and petalite substitution by montmorillonite and kaolinite instead of a higher Al content in white micas, especially because they are not present in all spectra.

Such subtle changes in wavelength positions are not detectable through multispectral sensors but are noticeable using hyperspectral data. For example, in the previous work conducted by Oshigami et al. [66], the wavelength position of the Al-OH absorptions allowed the distinction of lepidolite from Al-poor and Al-rich muscovite by applying different thresholds to the employed mineral indices. Despite some overlap in the position of the $\mathrm{Al}-\mathrm{OH}$ feature between lepidolite and the other Li-minerals, a similar approach could be employed to hyperspectral data to map lepidolite- and spodumene/petalitebearing areas.

\subsection{Effects of Alteration in the Spectral Signature of Li-Bearing Minerals}

Comparing the reflectance spectroscopy of altered petalite results (Figure 6) with the complementary petrographic/geochemical techniques (Table 1), it was possible to corroborate the presence of montmorillonite and illite in the same samples. Overall, the combination of methods was complementary, despite some contradictory mineral identification between XRD and reflectance spectroscopy. The XRD identified nontronite and Fe-bearing smectite, while the reflectance spectroscopy indicated montmorillonite and possibly saponite. Nonetheless, previous studies have shown that reflectance spectroscopy has a greater capacity to distinguish among different clay minerals and between clay minerals and illite and muscovite [48,52].

In general, the petalite alteration products' spectral behavior (Figure 6) is very similar to the one observed for petalite (Figure 4), with a dominance of montmorillonite and illite features. Kaolinite and saponite (Mg-smectite) were also observed. Regarding the main Al-OH feature (Figure A1, Appendix A), petalite alteration products show the widest range, reaching higher wavelengths than the ones observed for the three Li-bearing minerals. 
There is also a spectral similarity between petalite relics (HD.479 and BJ4-01) and entirely replaced crystals. The petalite relics found within highly altered areas show Li contents compatible with unaltered petalite [13], which may be explained by superficial alteration cover and the concentration of alteration on fractures, cleavage, and crystal border, as observed in Figure $5 \mathrm{c}-\mathrm{f}$ and Cardoso-Fernandes et al. [57]. Figure 7 shows an inverse correlation between the Li content and the hydroxyl and water features depth (Pearson's $r=0.95$ and 0.88 , respectively). However, it is not possible to estimate the Li content based on these parameters, because, at low Li concentrations, no trend was observed. From samples with preserved petalite relics to the wholly altered ones, there is an increase in the $\mathrm{OH}^{-}$and $\mathrm{H}_{2} \mathrm{O}$ absorption depth explained by higher amounts of alteration minerals since mineral abundance is related to the absorption intensity $[56,64,71]$. On its turn, a higher petalite substitution for alteration minerals such as clays leads to a decrease in Li content (Table 1 and Figure 7). The results indicate that the absorption intensity could be used to discriminate fresher petalite samples.

Despite the different climate, the resultant mineral alteration assemblage (montmorillonite and other smectite group minerals, illite, kaolinite) is very similar to the spodumene and petalite's supergene alteration paragenesis found in Brazil under tropical to subtropical climate [25]. Previous studies have shown that these alteration minerals can result from either supergene (weathering) or hydrothermal metasomatic alteration in the late stages of pegmatite crystallization $[57,68,72,73]$, which would explain the occurrence of the same mineral paragenesis under distinct weathering conditions. At the same time, the presence of clay minerals in microfractures in spodumene was already described by Clark et al. [50], causing the spectral behavior of spodumene to be dominated by the clay's absorption features. Therefore, it is not surprising that spodumene and petalite samples show similar spectral curves because the two minerals seem to undergo the same alteration phenomena.

Taking this into account, it is indisputable that the alteration deeply affects the spectral behavior of Li-minerals even when clay minerals are present in minimal amounts. Therefore, any possible spectral signature of petalite or spodumene in the VNIR-SWIR spectral range is obscured by the very pronounced clay-related features. This poses advantages and limitations in satellite-based Li-exploration. Since spodumene and petalite's spectral features are similar and because different alteration degrees produce the same spectral signal, the ability to spectrally identify spodumene or petalite using the same methodology is not compromised. This is in line with the results obtained with classical and machine learning techniques in the study area [21,23]. Additionally, the results indicate no need for different methodological approaches worldwide since the same mineral assemblages could be found in distinct climates. The work of Santos et al. [22] corroborated this interpretation, because the methods developed for Li-pegmatite identification in the Fregeneda-Almendra area also showed potential for Li-exploration in the Minas Gerais region (Brazil). The main limitation is the impossibility of the spectral features allow discrimination between the areas where spodumene and/or petalite occur from the areas where the weathering of other materials produced the clay minerals. This means that as in other deposits, clay minerals can be used as pathfinders for petalite or spodumene. Montmorillonite is identified through the diagnostic, broad, asymmetric, and acute absorptions around $\sim 1413 \mathrm{~nm}$ and $\sim 1911 \mathrm{~nm}$; the Al-OH feature at $2206 \mathrm{~nm}[48,49]$ shallower than the $1911 \mathrm{~nm}$ one; and the slight inflection around $\sim 1467 \mathrm{~nm}[1,49]$. Kaolinite has also diagnostic features, such as (i) a small inflection around $\sim 2165 \mathrm{~nm}$; (ii) the presence of an Al-OH triplet at $\sim 2312, \sim 2350$, and $\sim 2380 \mathrm{~nm}$; and (iii) double $\mathrm{OH}^{-}$and $\mathrm{Al}-\mathrm{OH}$ absorptions (not visible in poorly crystalline kaolinite) $[8,48,49,53]$. However, this pathfinder approach would only work in areas where argillic alteration is not predominant. In future attempts, the variation of absorption intensity related to proportions of Li content could be used to try to discriminate Li-bearing minerals from barren, clay-bearing areas as observed in Figure 7. The co-occurrence of cookeite (formed after petalite or spodumene alteration) could also be used to highlight Li-bearing areas. 


\subsection{Discrimination of Li-Pegmatites from the Remaining Lithologies}

The last objective of this work was to understand if Li-pegmatites can be discriminated from the remaining field lithologies. In general, it was possible to ascertain that all sampled lithologies present similar absorption features caused by water and/or hydroxyl present in the structure of rock-forming minerals (Figures 8 and 9 and Figure A2). This is due to the presence of white mica/illite in samples from all field lithologies and false-positive areas or due to the presence of montmorillonite in some samples.

Lepidolite, cookeite, and orthoclase were exclusively identified in Li-pegmatite samples. These minerals can be used, therefore, as targets or pathfinders for Li-bearing pegmatites. Lepidolite diagnostic features were already described in Section 5.1, while cookeite shows several diagnostic features, namely: (i) a broad, symmetric main $\mathrm{Al}-\mathrm{OH}$ feature, (ii) two $\mathrm{OH}^{-}$absorptions at $\sim 1580 \mathrm{~nm}$ and $\sim 1835 \mathrm{~nm}$, and (iii) a deep and broad $\mathrm{Mg}-\mathrm{OH}$ feature at $\sim 2355 \mathrm{~nm}[19,25,54,55]$. Orthoclase can be indirectly identified through (i) aqueous fluid inclusions with absorptions at $\sim 1410 \mathrm{~nm}$ and $\sim 1912 \mathrm{~nm}[47,55]$ and (ii) $\mathrm{NH}_{4}{ }^{+}$ substituting $\mathrm{K}^{+}$, with a diagnostic absorption at $\sim 2110 \mathrm{~nm}[49,61,62]$. Chlorite takes place in CXG and granodiorite samples. Biotite occurs in both granite and granodiorite samples, but the exclusive occurrence of phlogopite in the granodiorite allows discrimination between the two. Chlorite and/or biotite were also observed in false-positives areas 1, 3, and 4 . Montmorillonite and minor kaolinite compound the alteration assemblage of Li-pegmatites, granite, granodiorite, and false-positive areas 1-3. Altered samples of Li-pegmatite, granite, CXG, and false-positive areas 1-3 present iron oxides, predominantly goethite.

As verified, except for certain exclusive minerals or distinct mineral assemblages, other factors may need to be considered to achieve lithological discrimination fully. When considering the reflectance magnitude of the different classes (Figures 10 and A4), in general, altered samples show higher reflectance values when compared to the fresh ones, which is due to alteration minerals (such as clays and iron-oxides). Additionally, petaliteand lepidolite-bearing pegmatites present similar mean reflectance values, although the former can reach higher maximum values. The granite samples demonstrate the highest mean reflectance (Figure A4). These relative differences in magnitude help to discriminate between lithological types in data from multi- or hyperspectral sensors.

The wavelength position of given absorption features can also be helpful for lithological discrimination (Figures 11 and A5). The metasediments samples of the CXG show the $\mathrm{Al}-\mathrm{OH}$ absorption position at longer wavelengths which indicates that the white mica is Al-poor (Figure 11); Li-pegmatite samples present the main $\mathrm{Al}-\mathrm{OH}$ absorption at shorter wavelengths, similar to lepidolite; granitoid samples show an intermediate wavelength position and, therefore, Al content [7,49,52,64]. Despite the correlation between white mica composition and the wavelength position of the $\mathrm{Al}-\mathrm{OH}$ absorption, more recent studies have shown that Al-rich phengites can overlap the typical muscovite wavelength range $[7,8]$. Moreover, lepidolite and Li-rich micas are characterized by a lower $\mathrm{Al}$ content than muscovite due to Li substituting $\mathrm{Al}$ in octahedral sites [74]. This indicates that another factor is influencing the smaller wavelength of the $2200 \mathrm{~nm}$ feature. Additional research, namely detailed mineral chemistry studies, is needed to fully understand this issue. Nonetheless, there is a clear $2205 \mathrm{~nm}$ threshold that is useful for remote sensing applications, at least in this study area. Figure $11 \mathrm{~b}$ indicates that the $\mathrm{Al}-\mathrm{OH}$ position varies within the different sampled lithologies as the depth of the Al-OH absorption, which is more profound in Li-pegmatite and shallower in CXG samples (either from the training or false-positive areas). Considering this, it is possible to differentiate the CXG metasediments (host rocks) from the target class (Li-pegmatites). The difference between the two classes is even more pronounced when only the most spectrally pure samples are considered (full and half-full symbols of Figure 11). Such wavelength and depth variations could be evaluated using a hyperspectral sensor.

In what concerns the $\mathrm{Mg}-\mathrm{OH}$ wavelength position (Figure A5; Appendix A), it is not possible to discriminate between the metasedimentary rocks and granitoids due to the overlap of wavelengths. However, chlorite presents a similar wavelength position and 
possibly composition in both training and false-positive areas. Except for one Mg-rich chlorite/biotite in the granodiorite samples, all remaining features are compatible with intermediate $\mathrm{Mg} / \mathrm{Fe}$ compositions [49,59]. In the case of chlorite, the iron-related features in the VNIR range, the shape, position, and relative depth of the $\sim 2250 \mathrm{~nm}$ and $\sim 2350 \mathrm{~nm}$ absorptions are compatible with intermediate compositions with both $\mathrm{Fe}$ and $\mathrm{Mg}$ present. Nonetheless, it should be noted that the overlap with the white mica $\mathrm{Al}-\mathrm{OH}$ secondaries can lead to shifts in the $\mathrm{Mg}-\mathrm{OH}$ position.

\subsection{Potential of Li-Exploration Using Satellite Data}

The previous results indicate that the potential use of remote sensing data is highly dependent on the sensors. As seen in Figure 12, the spectral behavior of the CXG metasediments is very distinct from the remaining lithologies, even for the Sentinel-2 and Landsat-8 OLI. However, the Al-OH absorption around $\sim 2200 \mathrm{~nm}$ is only recognized in higher resolution sensors (ASTER, PRISMA, and Mjolnir). The existence of a band in this region increases the separability of the CXG metasedimentary class. The granodiorite samples are also spectrally distinct from Li-bearing pegmatites. The most significant similarity is observed between granite and Li-pegmatite samples. The hyperspectral sensors can identify the same wavelength shifts observed in the laboratory (Figure 11) that can help to discriminate them. Nonetheless, PRISMA has advantages over the Mjolnir sensor since the VNIR features can increase the separability of the two classes. On the other hand, when on board aircraft and UAVs, the Mjolnir sensor has a better spatial resolution, reducing the components in spectral mixtures.

Considering the results, it is possible to infer that although the distinct lithologies present similar absorption features, it is possible to spectrally discriminate Li-pegmatites from other lithologies using remote sensing data due to (i) the higher reflectance magnitude, (ii) more profound $\mathrm{Al}-\mathrm{OH}$ absorption depths, and (iii) shifts in the wavelength position of the Al-OH features. Furthermore, distinct mineral assemblages result in particular spectral behavior (e.g., Li-pegmatites lack chlorite/biotite features in the VNIR region while presenting important and exclusive target minerals). The false-positive areas, for example, despite showing similar clay-related absorptions, also display distinct VNIR features. Of course, the ability to discriminate the target class from the remaining outcropping lithologies increases with an increasing spectral resolution (Figure 12), showing the importance of hyperspectral sensors such as PRISMA or Mjolnir. The capability to spectrally discriminate Li-pegmatites using hyperspectral data needs to be validated in further studies in a real-life application and not only using simulated hyperspectral data (e.g., $[8,65,66])$.

\section{Conclusions}

Analyzing the wavelength, shape, and symmetry of diagnostic absorption features, as well as the overall reflectance magnitude and absorption depths of a Li-dedicated spectral library, allowed the identification of the spectral mineralogy and characterization of samples of (i) different Li-bearing minerals, (ii) several field lithologies of the study area, and (iii) samples from areas previously misclassified as Li-pegmatite using a machine learning algorithm. Ultimately, the results obtained allowed evaluation of the potential of remote sensing and spectral data in Li-exploration, thus fulfilling the proposed objectives and addressing the main research questions:

1. Can Li-bearing minerals be distinguished from each other and other minerals? The spectra obtained allowed the discrimination of lepidolite from spodumene, petalite, and other white micas. However, it was not possible to distinguish petalite from spodumene because clay-related absorption features dominate the spectra of both Li-minerals, thus obscuring any likely diagnostic spectral behavior. This implies that spodumene and petalite can only be indirectly identified. Several factors, such as the VNIR features or the position of the main $\mathrm{Al}-\mathrm{OH}$ absorption, enable direct lepidolite identification through multi- or hyperspectral satellite data. 
2. How can the alteration products affect the spectral signature of Li-bearing minerals? The complementary petrography and geochemical studies proved that the same alteration minerals observed in previous studies occur in either well-preserved or completely altered samples. However, the clay-related absorption depths are much smaller for petalite relics. Further studies are needed to understand if the clay minerals formed from petalite alteration in the Fregeneda-Almendra region are related to weathering or metasomatic processes. Therefore, the effect of alteration paragenesis is paramount in the spectral behavior of spodumene and petalite, thus limiting the possibility to discriminate areas where these Li-minerals occur from heavily altered, barren areas through multispectral data. On the other hand, using hyperspectral data could overcome this limitation, either through the possibility of recognizing variable absorption depths (distinct amounts of clay minerals) or by the identification of other alteration minerals exclusively related to Li-minerals such as cookeite. Notwithstanding, in areas where clay-related alteration is not prevalent, the same methodology can be employed, using montmorillonite and kaolinite as pathfinders to identify spodumene and petalite worldwide since the alteration paragenesis is similar to the described in tropical conditions.

3. Can Li-pegmatites be spectrally discriminated from other lithologies in a supervised classification attempt? Despite the similar absorption features, we conclude that the satellite data can map Li-pegmatites through several criteria such as (i) the distinctive reflectance magnitude, (ii) higher absorptions depths, (iii) distinct wavelength position of key absorption features, and (iv) particular overall spectral behavior reflecting different mineral assemblages. Minerals such as lepidolite, cookeite, and orthoclase can work as targets for Li-pegmatites. Further studies are needed to evaluate the performance of hyperspectral data in real-life conditions and compare it with the laboratory-simulated hyperspectral data.

The results and conclusions withdrawn in this work provide valuable insights on the spectral behavior of pegmatite-hosted Li mineralization and minerals, allowing for more reasoned and directed satellite-based approaches in the future, based on the proposed strategies and pathfinders. Additional studies are needed to continue improving the knowledge on the alteration paragenesis and to understand the smaller wavelength of the $\sim 2200 \mathrm{~nm}$ feature in lepidolite and its relationship with the $\mathrm{Li}$ and $\mathrm{Al}$ contents in the octahedral layer.

Supplementary Materials: The following are available online at https:/ /www.mdpi.com/article/10 .3390/rs13183688/s1: Table S1: Spectral mineralogy of Li-minerals, Table S2: Spectral mineralogy of the training areas, and Table S3: Spectral mineralogy of the false-positive areas.

Author Contributions: Conceptualization, J.C.-F., A.L. and A.C.T.; methodology, J.C.-F., A.L. and A.C.T.; software, J.C.-F.; formal analysis, J.C.-F., J.S., M.M.P., A.L., M.A.R. and F.D.; investigation, J.C.-F., J.S., F.D., A.L., A.C.T., M.M.P. and M.A.R.; resources, A.L., E.R-R., O.B. and J.C.; data curation, J.C.-F., J.S. and F.D.; writing - original draft preparation, J.C.-F.; writing - review and editing, all the remaining authors; visualization, J.C.-F.; supervision, A.L., A.C.T., M.A.R., M.M.P., E.R.-R. and O.B.; project administration, J.C., A.L. and A.C.T.; and funding acquisition, J.C. and A.L. All authors have read and agreed to the published version of the manuscript.

Funding: The authors would like to thank the financial support provided by FCT-Fundação para a Ciência e a Tecnologia, I.P., with the ERA-MIN/0001/2017-LIGHTS project and, also, with the 869274-GREENPEG-H2020-SC5-2018-2019-2020 project. This work was also supported by national funds through the FCT project UIDB/04683/2020-ICT (Institute of Earth Sciences). Joana CardosoFernandes and Filipa Dias were financially supported within the compass of their respective Ph.D. theses, ref. SFRH/BD/136108/2018 and ref. 2020.05534.BD, by national funds from MCTES through FCT and co-financed by the European Social Fund (ESF) through POCH-Programa Operacional Capital Humano and NORTE 2020 regional program. The Spanish Ministerio de Ciencia, Innovacion y Universidades (Project RTI2018-094097-B-100, with ERDF funds) and the University of Basque County (UPV/EHU) (grant GIU18/084) also contributed economically. The French National Research 
Agency (ANR-10-LABX 21-LABEX RESSOURCES 21) partly supported the Master Student personal grant, and the 776804-NEXT-H2020-SC5-2017 project participated in equipment purchasing.

Institutional Review Board Statement: Not applicable.

Informed Consent Statement: Not applicable.

Data Availability Statement: The data presented in this study are openly available in Zenodo at http:/ / doi.org/10.5281/zenodo.4575375, accessed on 12 September 2021, reference number [46].

Conflicts of Interest: The authors declare no conflict of interest. The funders had no role in the design of the study; in the collection, analyses, or interpretation of the data; in the writing of the manuscript; or in the decision to publish the results.

\section{Appendix A}

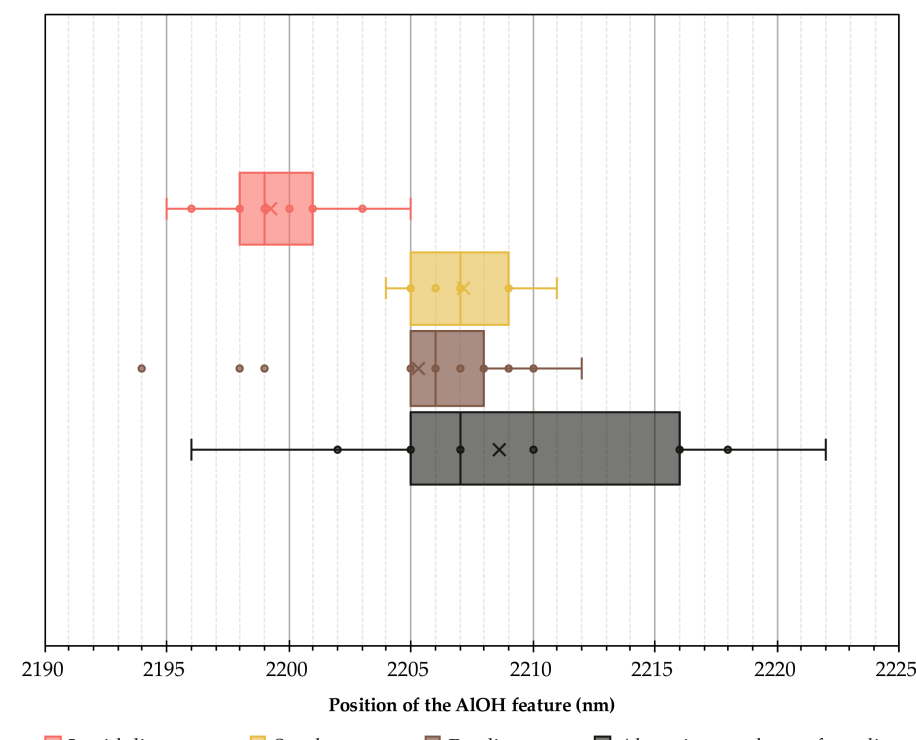

Figure A1. Boxplot diagrams of the main Al-OH absorption wavelength position for the Li minerals and associated alteration products.

Table A1. Description of each false-positive site and respective collected samples. Mineralogical information was collected with optical microscopy and reflectance spectroscopy. Ap—apatite; Bt—biotite; Chl—chlorite; Goe—goethite; Il—illite; IO— iron oxides/hydroxides; Mnt—montmorillonite; Pl—plagioclase; Qtz—quartz; Tur—tourmaline; Ser—sericite; WM—white mica; $\mathrm{Zr}$-zircon.

\begin{tabular}{|c|c|c|c|c|}
\hline False-Positive Area & Site Description & Lithology & Petrography & Spectroscopy \\
\hline $\begin{array}{c}1 \\
\text { (GPS point } 443)\end{array}$ & $\begin{array}{l}\text { Wine plantation; } \\
\text { disturbed soil with } \\
\text { many rock boulders }\end{array}$ & $\begin{array}{c}\text { CXG metasediments: } \\
\text { A1 *-striped phyllites interbed } \\
\text { with metagraywacke benches; } \\
\text { A2-light-colored phyllite. } \\
\text { Ordovician metasediments: }\end{array}$ & $\begin{array}{c}\text { A1: WM/Ser, } \mathrm{Qtz}, \mathrm{IO}, \mathrm{Bt}, \mathrm{Pl}, \mathrm{Chl} \text {, } \\
\text { Tur, detrital WM, detrital } \mathrm{Zr} \text {, } \\
\text { opaque minerals }\end{array}$ & $\begin{array}{l}\text { Il, Mnt, WM, } \\
\text { Chl/Bt, Goe and } \\
\text { other IO, Qtz? }\end{array}$ \\
\hline $\begin{array}{c}2 \\
\text { (GPS point } 444)\end{array}$ & $\begin{array}{l}\text { Hillside area; slope } \\
\text { deposits }\end{array}$ & $\begin{array}{c}\text { A1-whitish impure quartzite } \\
\text { (metapsamite) with a ferruginous } \\
\text { crust; } \\
\text { A2/A3-reddish, ferruginous } \\
\text { impure quartzite. }\end{array}$ & A1: Qtz, WM, IO, detrital Zr, Tur & $\begin{array}{l}\text { WM, Qtz, Il, Goe, } \\
\text { Kao }\end{array}$ \\
\hline $\begin{array}{c}3 \\
\text { (GPS point } 445)\end{array}$ & $\begin{array}{l}\text { Olive plantation; } \\
\text { sparse rock boulders }\end{array}$ & $\begin{array}{c}\text { CXG metasediments: } \\
\text { A1/A2-striped phyllites interbed } \\
\text { with metagraywacke benches. } \\
\text { A3-pegmatite. }\end{array}$ & $\begin{array}{l}\text { A2: WM/Ser, Qtz, Chl, detrital } \\
\text { WM, Pl, IO, Ap, opaque minerals }\end{array}$ & $\begin{array}{l}\text { Mnt, Il, Chl/Bt, } \\
\text { Goe and other IO, } \\
\text { Qtz? }\end{array}$ \\
\hline $\begin{array}{c}4 \\
\text { (GPS point 446) }\end{array}$ & $\begin{array}{l}\text { Almond plantation; } \\
\text { disperse rock boulders }\end{array}$ & $\begin{array}{l}\text { CXG metasediments: } \\
\text { A1/A2-striped phyllites interbed } \\
\text { with metagraywacke benches }\end{array}$ & $\begin{array}{c}\text { A1: Qtz, WM/Ser, Bt, Pl, detrital } \\
\text { WM, Tur, IO, detrital Zr, Ap, } \\
\text { opaque minerals }\end{array}$ & WM, Ser, Chl \\
\hline
\end{tabular}

${ }^{*}$ A1 to An: numeration given to different samples collected in the same area (where $\mathrm{n}$ equals to the total number of samples). 

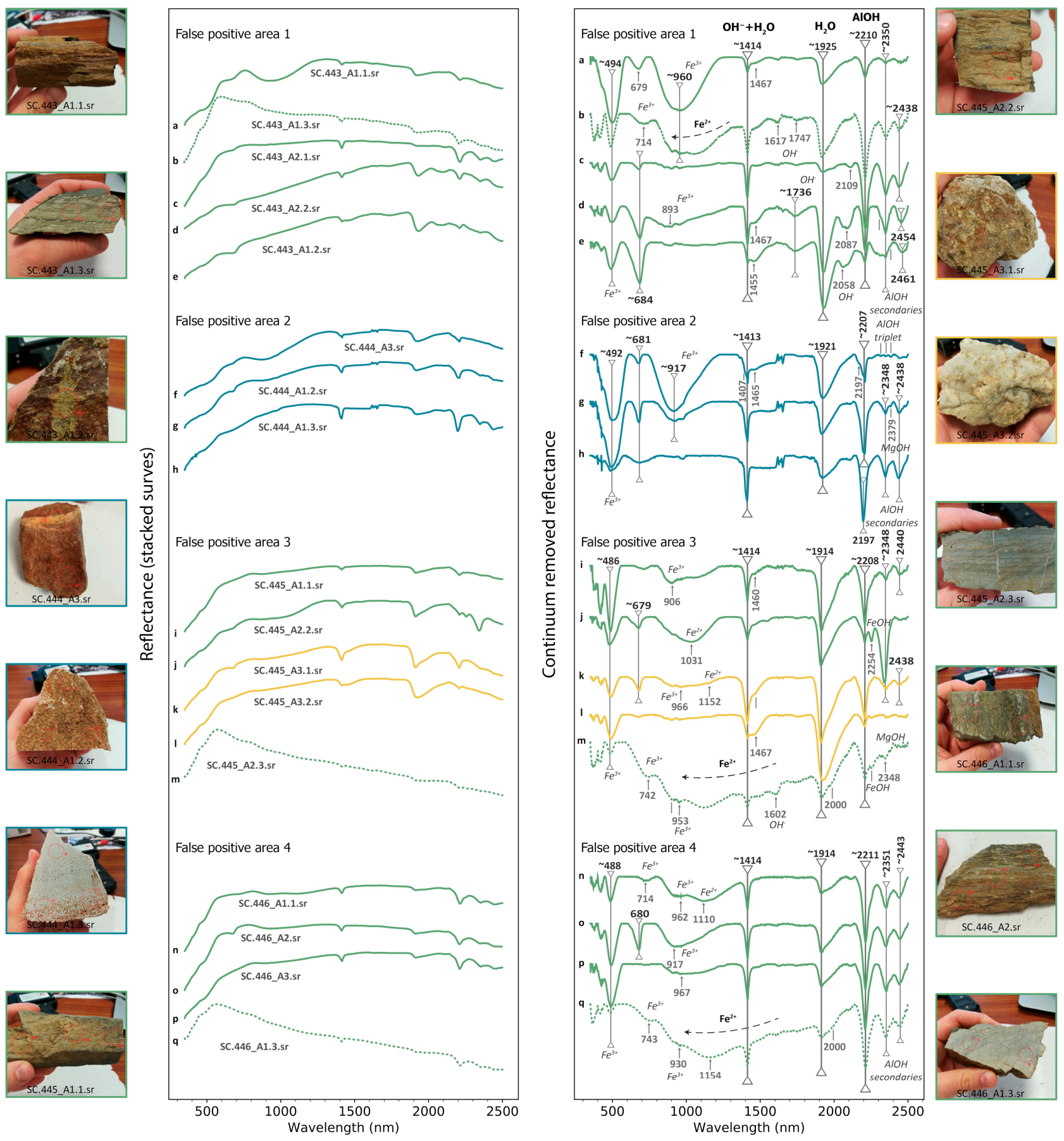

Figure A2. Spectral signature of samples collected in areas misclassified as Li-pegmatite in a previous classification attempt: reflectance curves (to the left) and continuum removed curves (to the right). The main absorption features are highlighted, and sample photographs are provided. Dotted curves: fresh samples; full curves: samples with visible signs of weathering. Each spectrum has a database code [45] providing information about the type of sample (SC-spectral confusion), a three-digit numerical part representing the GPS code, a one- or two-digit code representing the spectra number or the averaged spectra numbers, and a reference to the spectroradiometer employed (sr-SR-6500; asd-FieldSpec 4). 


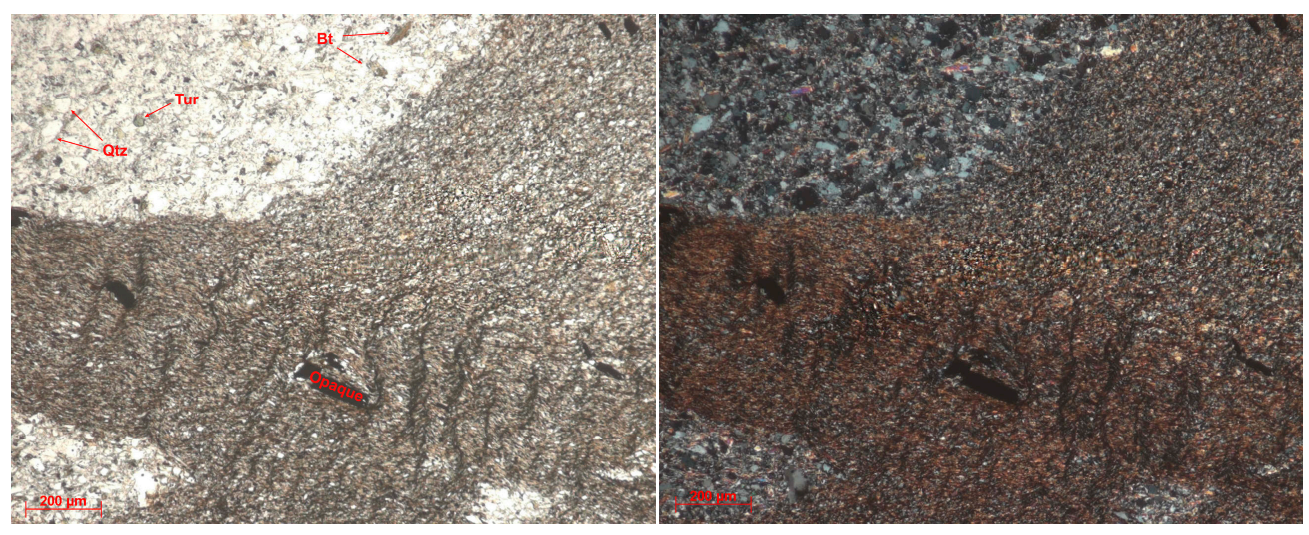

(a)

(b)



(c)

(d)

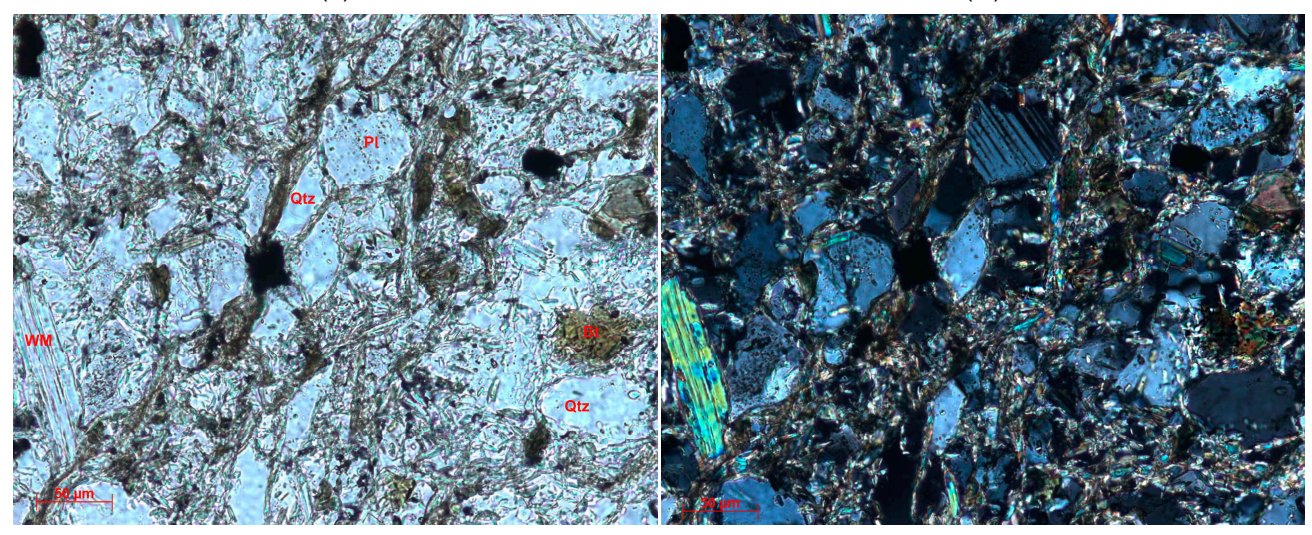

(e)

(f)

Figure A3. Photomicrographs of the CXG samples collected in the areas misclassified as Li-pegmatite. $(\mathbf{a}, \mathbf{b})$ Alternations of thin, micaceous layers and coarser metagraywacke beds (load cast structures) in parallel polarized light $-\mathrm{ppl}(\mathbf{a})$ and cross-polarized light $-\mathrm{cpl}(\mathbf{b})$. (c-f) The general aspects of the metagraywacke benches in $\mathrm{ppl}(\mathbf{c}, \mathbf{e})$ and $\mathrm{cpl}(\mathbf{d}, \mathbf{f})$. Bt-biotite; Pl—plagioclase; Qtz-quartz; Tur-tourmaline; WM-white mica. 


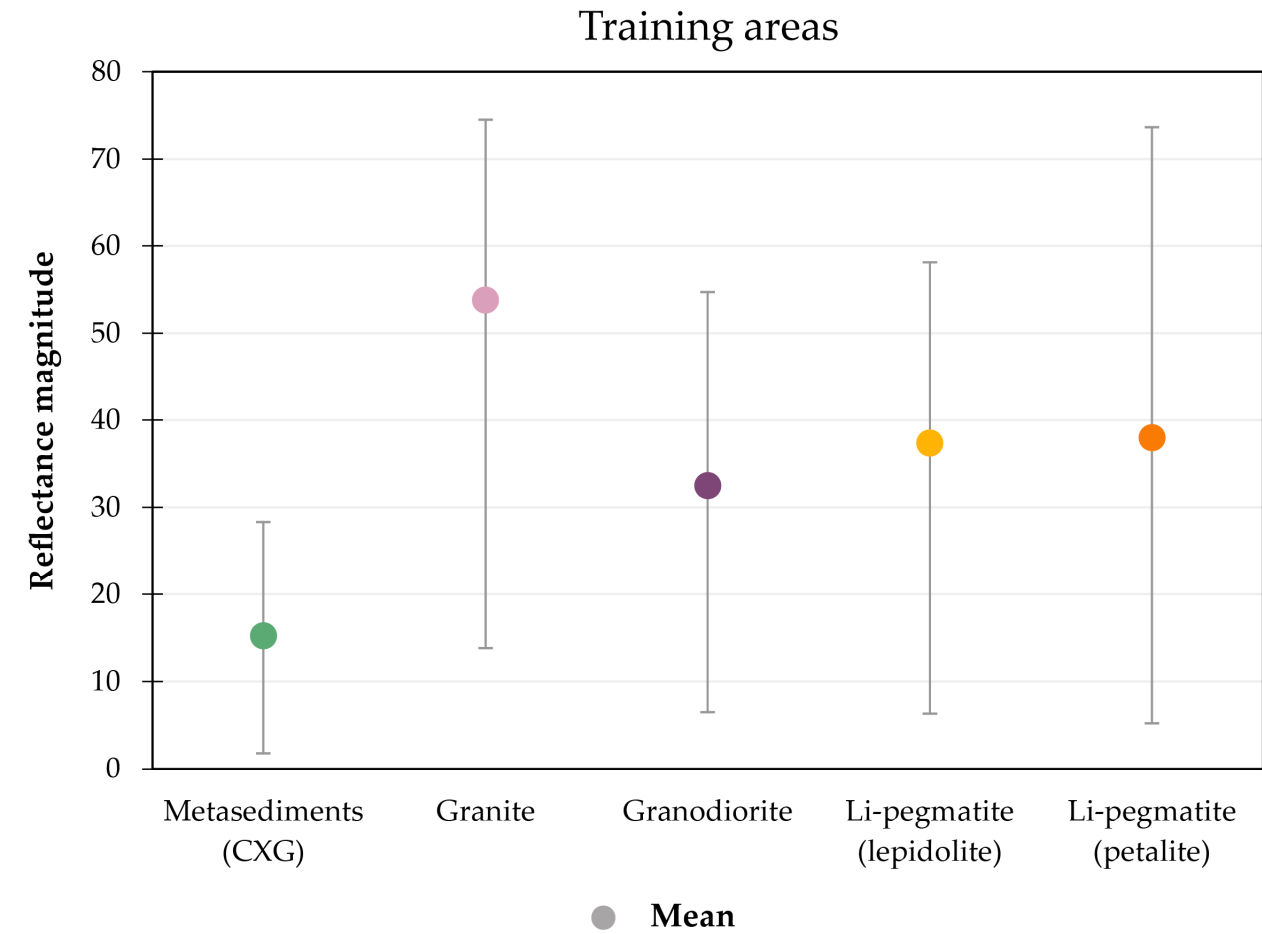

Figure A4. Minimum, maximum, and mean reflectance magnitudes of the different training area lithologies.

\section{Chlorite/biotite composition}

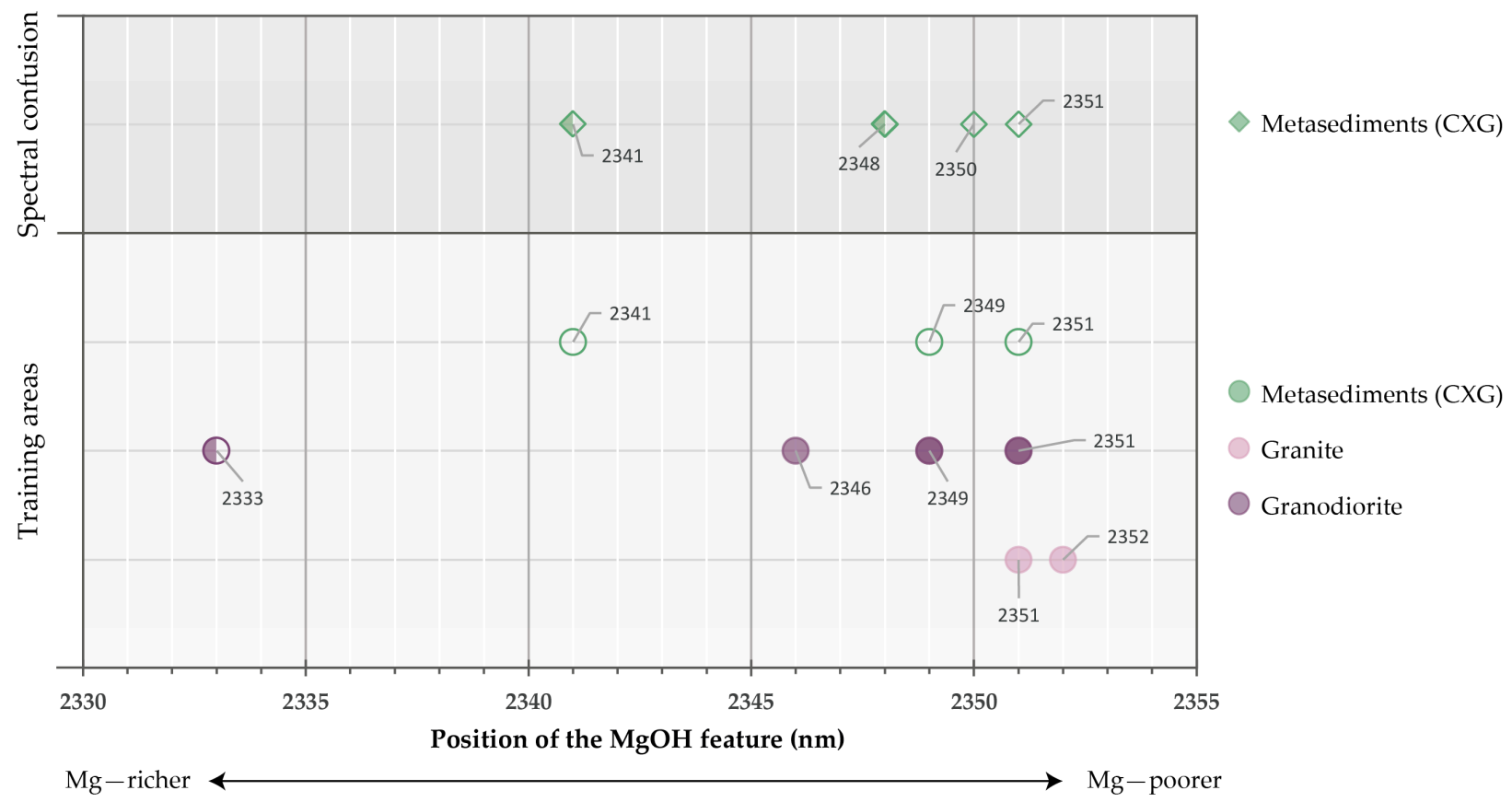

Figure A5. Comparison of the $\mathrm{Mg}-\mathrm{OH}$ wavelength position of biotites and chlorites from the CXG metasediments and granitoid rocks. Full symbols correspond to biotite; empty symbols correspond to chlorite; half-full symbols represent chlorite and biotite mixtures or samples where it was not possible to discriminate between the two minerals. 


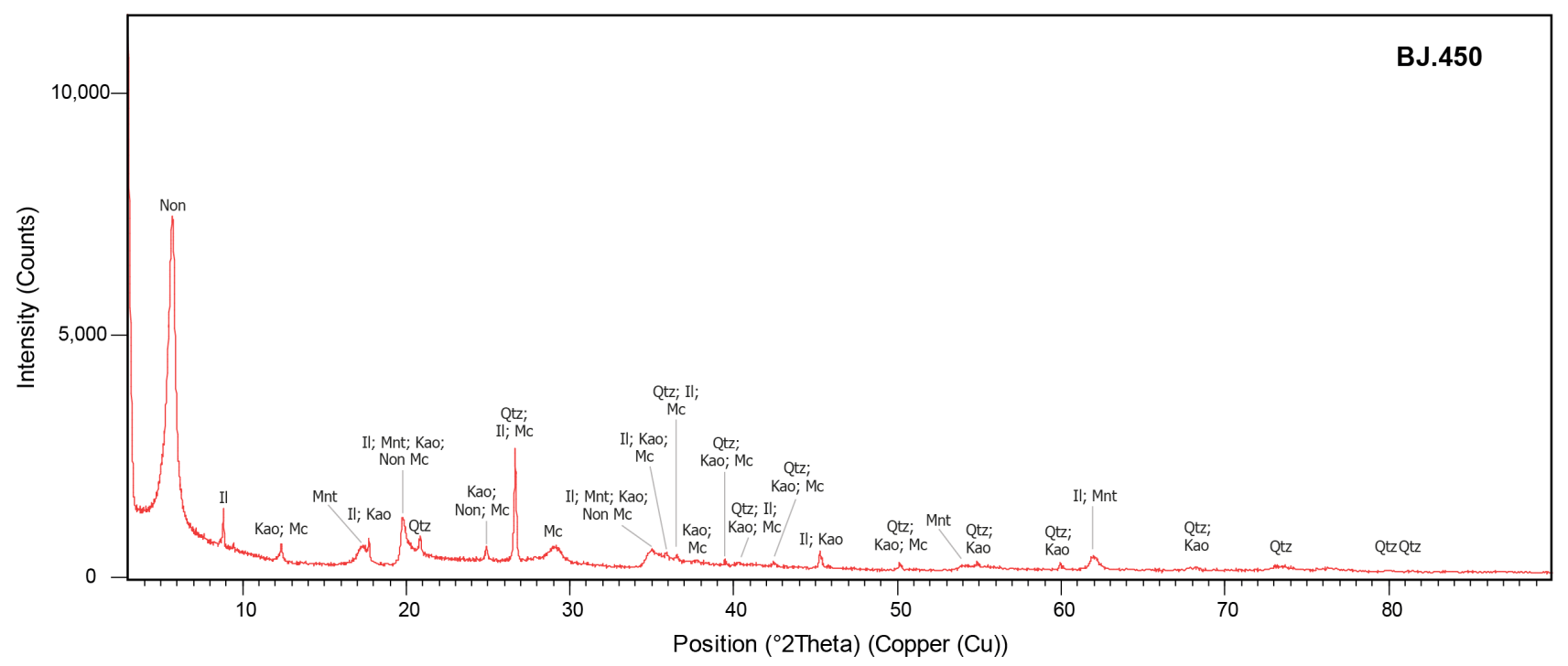

(a)

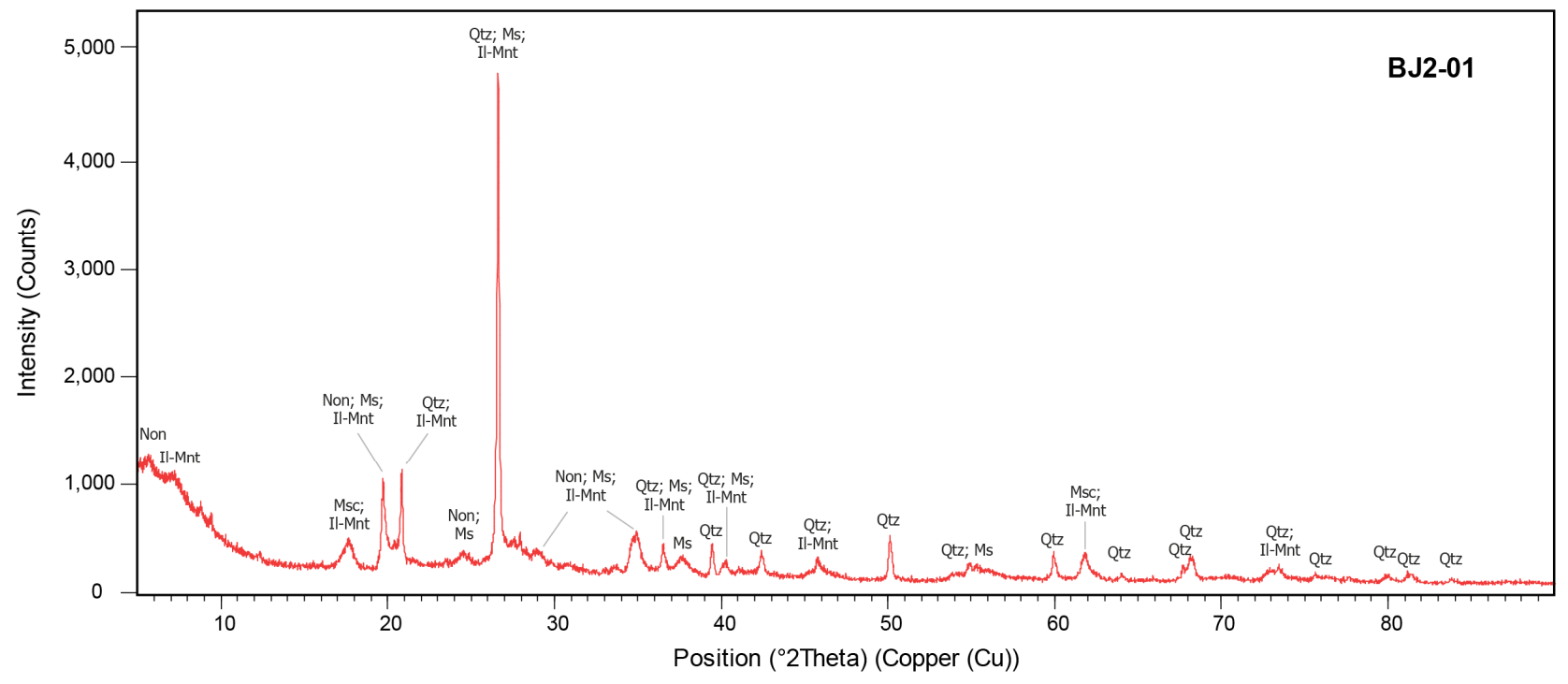

(b)

Figure A6. Cont. 




(c)

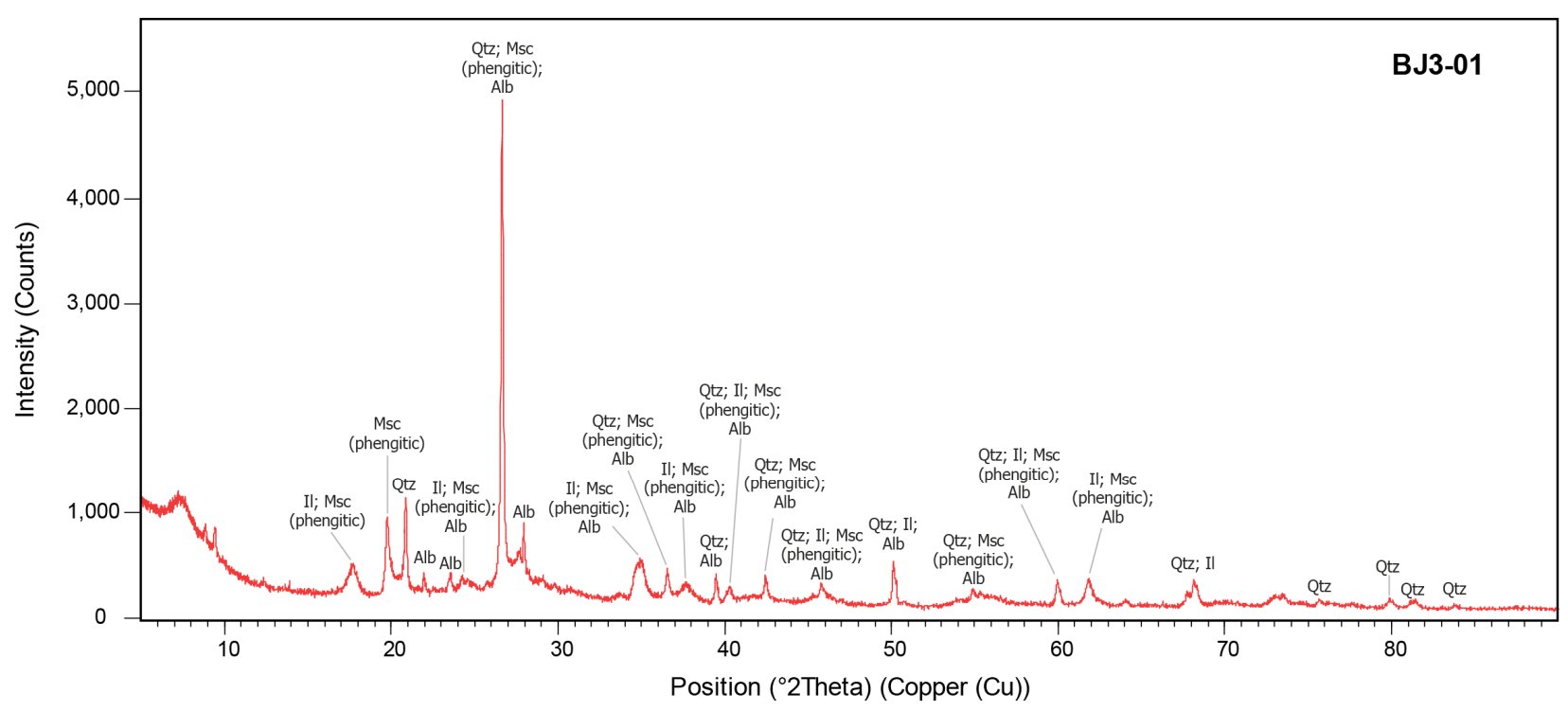

(d)

Figure A6. X-ray diffractograms of the selected samples of altered petalite crystals: (a) BJ.450, (b) BJ2-01, (c) BJ2-02, and (d) BJ3-01. Alb—albite; Il—illite; Kao—kaolinite; Mnt—montmorillonite; Msc—muscovite; Non—nontronite; Ororthoclase; Qtz—quartz; Sep—sepiolite. 


\section{References}

1. Lypaczewski, P.; Rivard, B.; Lesage, G.; Byrne, K.; D’Angelo, M.; Lee, R.G. Characterization of Mineralogy in the Highland Valley Porphyry Cu District Using Hyperspectral Imaging, and Potential Applications. Minerals 2020, 10, 473. [CrossRef]

2. Laakso, K.; Peter, J.M.; Rivard, B.; Gloaguen, R. Combined hyperspectral and lithogeochemical estimation of alteration intensities in a volcanogenic massive sulfide deposit hydrothermal system: A case study from Northern Canada. In Proceedings of the 2016 8th Workshop on Hyperspectral Image and Signal Processing: Evolution in Remote Sensing (WHISPERS), Los Angeles, CA, USA, 21-24 August 2016; pp. 1-5. [CrossRef]

3. Laakso, K.; Peter, J.M.; Rivard, B.; White, H.P. Short-Wave Infrared Spectral and Geochemical Characteristics of Hydrothermal Alteration at the Archean Izok Lake $\mathrm{Zn}-\mathrm{Cu}-\mathrm{Pb}-\mathrm{Ag}$ Volcanogenic Massive Sulfide Deposit, Nunavut, Canada: Application in Exploration Target Vectoring. Econ. Geol. 2016, 111, 1223-1239. [CrossRef]

4. Turner, D.; Rivard, B.; Groat, L. Rare earth element ore grade estimation of mineralized drill core from hyperspectral imaging spectroscopy. In Proceedings of the 2014 IEEE Geoscience and Remote Sensing Symposium, Quebec City, QC, Canada, 13-18 July 2014; pp. 4612-4615. [CrossRef]

5. Möller, V.; Williams-Jones, A.E. A hyperspectral study (V-NIR-SWIR) of the Nechalacho REE-Nb-Zr deposit, Canada. J. Geochem. Explor. 2018, 188, 194-215. [CrossRef]

6. Sun, Y.; Seccombe, P.K.; Yang, K. Application of short-wave infrared spectroscopy to define alteration zones associated with the Elura zinc-lead-silver deposit, NSW, Australia. J. Geochem. Explor. 2001, 73, 11-26. [CrossRef]

7. Tappert, M.C.; Rivard, B.; Giles, D.; Tappert, R.; Mauger, A. The mineral chemistry, near-infrared, and mid-infrared reflectance spectroscopy of phengite from the Olympic Dam IOCG deposit, South Australia. Ore Geol. Rev. 2013, 53, 26-38. [CrossRef]

8. Naleto, J.L.C.; Perrotta, M.M.; Costa, F.G.d.; de Souza Filho, C.R. Point and imaging spectroscopy investigations on the Pedra Branca orogenic gold deposit, Troia Massif, Northeast Brazil: Implications for mineral exploration in amphibolite metamorphicgrade terrains. Ore Geol. Rev. 2019, 107, 283-309. [CrossRef]

9. Linnen, R.L.; Van Lichtervelde, M.; Černý, P. Granitic Pegmatites as Sources of Strategic Metals. Elements 2012, 8, 275-280. [CrossRef]

10. Goodenough, K.M.; Shaw, R.A.; Smith, M.; Estrade, G.; Marqu, E.; Bernard, C.; Nex, P. Economic mineralization in pegmatites: Comparing and contrasting NYF and LCT examples. Can. Mineral. 2019, 57, 753-755. [CrossRef]

11. Kesler, S.E.; Gruber, P.W.; Medina, P.A.; Keoleian, G.A.; Everson, M.P.; Wallington, T.J. Global lithium resources: Relative importance of pegmatite, brine and other deposits. Ore Geol. Rev. 2012, 48, 55-69. [CrossRef]

12. Selway, J.B.; Breaks, F.W.; Tindle, A.G. A Review of Rare-Element (Li-Cs-Ta) Pegmatite Exploration Techniques for the Superior Province, Canada, and Large Worldwide Tantalum Deposits. Explor. Min. Geol. 2005, 14, 1-30. [CrossRef]

13. Dill, H.G. Pegmatites and aplites: Their genetic and applied ore geology. Ore Geol. Rev. 2015, 69, 417-561. [CrossRef]

14. Steiner, B.M. Tools and Workflows for Grassroots Li-Cs-Ta (LCT) Pegmatite Exploration. Minerals 2019, 9, 499. [CrossRef]

15. Zhang, A.; Wang, R.; Li, Y.; Hu, H.; Lu, X.; Ji, J.; Zhang, H. Tourmalines from the Koktokay No.3 pegmatite, Altai, NW China: Spectroscopic characterization and relationships with the pegmatite evolution. Eur. J. Mineral. 2008, 20, 143-154. [CrossRef]

16. Carrino, T.A.; de Brito Barreto, S.; de Oliveira, P.J.A.; de Araújo Neto, J.F.; de Lima Correia, A.M. Linking gemology and spectral geology: A case study of elbaites from Seridó Pegmatite Province, Northeastern Brazil. Braz. J. Geol. 2019, 49. [CrossRef]

17. Bocchio, R.; Adamo, I.; Caucia, F. Aquamarine from the Masino-Bregaglia Massif, Central Alps, Italy. Gems Gemol. 2009, 45, 204-207. [CrossRef]

18. de Araújo Neto, J.F.; de Brito Barreto, S.; Carrino, T.A.; Müller, A.; de Lira Santos, L.C.M. Mineralogical and gemological characterization of emerald crystals from Paraná deposit, NE Brazil: A study of mineral chemistry, absorption and reflectance spectroscopy and thermal analysis. Braz. J. Geol. 2019, 49. [CrossRef]

19. da Silva, S.M.P.; Crósta, A.P.; Angélica, R.S.; Beurlen, H.; da Silva, M.R.R. Mineralogical characterization and mapping using reflectance spectroscopy: An experiment at Alto do Giz pegmatite in the south portion of Borborema Pegmatite Province (BPP), northeastern Brazil. Estud. Geol. 2009, 19, 337-342.

20. Cardoso-Fernandes, J.; Lima, A.; Roda-Robles, E.; Teodoro, A.C. Constraints and potentials of remote sensing data/techniques applied to lithium (Li)-pegmatites. Can. Mineral. 2019, 57, 723-725. [CrossRef]

21. Cardoso-Fernandes, J.; Teodoro, A.C.; Lima, A. Remote sensing data in lithium (Li) exploration: A new approach for the detection of Li-bearing pegmatites. Int. J. Appl. Earth Obs. Geoinf. 2019, 76, 10-25. [CrossRef]

22. Santos, D.; Teodoro, A.; Lima, A.; Cardoso-Fernandes, J. Remote sensing techniques to detect areas with potential for lithium exploration in Minas Gerais, Brazil. In Proceedings of the SPIE Remote Sensing, Strasbourg, France, 9-12 September 2019; Schulz, K., Michel, U., Nikolakopoulos, K.G., Eds.; SPIE: Bellingham, WA, USA, 2019. [CrossRef]

23. Cardoso-Fernandes, J.; Teodoro, A.C.; Lima, A.; Roda-Robles, E. Semi-Automatization of Support Vector Machines to Map Lithium (Li) Bearing Pegmatites. Remote Sens. 2020, 12, 2319. [CrossRef]

24. Gao, Y.; Bagas, L.; Li, K.; Jin, M.; Liu, Y.; Teng, J. Newly Discovered Triassic Lithium Deposits in the Dahongliutan Area, NorthWest China: A Case Study for the Detection of Lithium-Bearing Pegmatite Deposits in Rugged Terrains Using Remote-Sensing Data and Images. Front. Earth Sci. 2020, 8, 553. [CrossRef]

25. Costa, M.A.C.; Perrotta, M.M.; Melo, T.G.; Turra, B. Estudos Espectrais. In Avaliação do Potencial do Litio no Brasil: Área do Médio Rio Jequitinhonha, Nordeste de Minas Gerais: Texto Explicativo e Mapas; Paes, V.J.C., Santos, L.D., Tedeschi, M.F., Betiollo, L.M., Eds.; CPRM: Belo Horizonte, MG, Brazil, 2016; p. 276. 
26. Vieira, R. Aplitopegmatitos com Elementos Raros da Região Entre Almendra (V.N. de Foz Côa) e Barca d'Alva (Figueira de Castelo Rodrigo). Campo Aplitopegmatítico da Fregeneda-Almendra. Ph.D. Thesis, Faculdade de Ciências da Universidade do Porto, Porto, Portugal, 2010.

27. Roda, E. Distribución, Caracteristicas y Petrogenesis de las Pegmatitas de La Fregeneda (Salamanca). Ph.D. Thesis, Facultad de Ciencia y Tecnología de la Universidad del País Vasco (UPV/EHU), Bilbao, Spain, 1993.

28. Cardoso-Fernandes, J.; Teodoro, A.C.; Lima, A.; Roda-Robles, E. Evaluating the performance of support vector machines (SVMs) and random forest (RF) in Li-pegmatite mapping: Preliminary results. In Proceedings of the SPIE Remote Sensing, Strasbourg, France, 9-12 September 2019; Schulz, K., Michel, U., Nikolakopoulos, K.G., Eds.; SPIE: Bellingham, WA, USA, 2019. [CrossRef]

29. Cardoso-Fernandes, J.; Silva, J.; Lima, A.; Teodoro, A.C.; Perrotta, M.; Cauzid, J.; Roda-Robles, E. Characterization of lithium (Li) minerals from the Fregeneda-Almendra region through laboratory spectral measurements: A comparative study. In Earth Resources and Environmental Remote Sensing/GIS Applications XI; SPIE: Bellingham, WA, USA, 2020. [CrossRef]

30. Cardoso-Fernandes, J.; Silva, J.; Lima, A.; Teodoro, A.C.; Perrotta, M.; Cauzid, J.; Roda-Robles, E.; Ribeiro, M.A. Reflectance spectroscopy to validate remote sensing data/algorithms for satellite-based lithium (Li) exploration (Central East Portugal). In Earth Resources and Environmental Remote Sensing/GIS Applications XI; SPIE: Bellingham, WA, USA, 2020. [CrossRef]

31. Roda-Robles, E.; Pesquera, A.; Velasco, F.; Fontan, F. The granitic pegmatites of the Fregeneda area (Salamanca, Spain): Characteristics and petrogenesis. Mineral. Mag. 1999, 63, 535-558. [CrossRef]

32. da Costa, J.C.S. Notícia Sobre Uma Carta Geológica do Buçaco, de Nery Delgado; Serviços Geológicos de Portugal: Lisboa, Portugal, 1950.

33. Teixeira, C. Notas Sobre Geologia de Portugal o Complexo Xisto-Grauváquico Ante-Ordoviciano; Empresa Literaria Fluminense Lda.: Lisboa, Portugal, 1955; p. 48.

34. Rodríguez Alonso, M.D.; Díez Balda, M.A.; Perejón, A.; Pieren, A.; Liñán, E.; López Díaz, F.; Moreno, F.; Gámez Vintaned, J.A.; Gónzalez Lodeiro, F.; Martínez Poyatos, D.; et al. Domínio del Complejo Esquisto-Grauváquico: Estratigrafía. La secuencia litoestratigráfica del Neoproterozóico-Câmbrico Inferior. In Geología de España; Vera, J.A., Ed.; Geológica de España-Instituto Geológico y Minero de España (SGE-IGME): Madrid, Spain, 2004; pp. 78-81.

35. Pereira, I.; Dias, R.; Bento dos Santos, T.; Mata, J. Exhumation of a migmatite complex along a transpressive shear zone: Inferences from the Variscan Juzbado-Penalva do Castelo Shear Zone (Central Iberian Zone). J. Geol. Soc. 2017, 174, 1004. [CrossRef]

36. Ferreira, J.A.; Bento dos Santos, T.; Pereira, I.; Mata, J. Tectonically assisted exhumation and cooling of Variscan granites in an anatectic complex of the Central Iberian Zone, Portugal: Constraints from LA-ICP-MS zircon and apatite U-Pb ages. Int. J. Earth Sci. 2019, 108, 2153-2175. [CrossRef]

37. da Silva, A.F.; Ribeiro, M.L. Notícia Explicativa da Folha 15-A: Vila Nova de Foz Côa; Serviços Geológicos de Portugal: Lisboa, Portugal, 1991; p. 52.

38. da Silva, A.F.; Ribeiro, M.L. Notícia Explicativa da Folha 15-B: Freixo de Espada à Cinta; Instituto Geológico e Mineiro: Lisboa, Portugal, 1994; p. 48.

39. Silva, A.F.; Santos, A.J.; Ribeiro, A.; Cabral, J.; Ribeiro, M.L. Carta Geológica de Portugal na Escala 1/50.000-Folha 15-B-Freixo de Espada à Cinta; Serviços Geológicos de Portugal: Lisboa, Portugal, 1990.

40. Silva, A.F.; Santos, A.J.; Ribeiro, A.; Ribeiro, M.L. Carta Geológica de Portugal na Escala 1/50.000-folha 15-A-Vila Nova de Foz Côa; Serviços Geológicos de Portugal: Lisboa, Portugal, 1990.

41. ASD Inc. ViewSpec Pro ${ }^{\mathrm{TM}}$ User Manual; ASD Document 600555 Rev. A; ASD Inc.: Boulder, CO, USA, 2008.

42. Menges, F. Spectragryph-Optical Spectroscopy Software, Version 1.2.14. Available online: http://www.effemm2.de/ spectragryph/ (accessed on 22 July 2020).

43. Clark, R.N.; Roush, T.L. Reflectance spectroscopy: Quantitative analysis techniques for remote sensing applications. J. Geophys. Res. Solid Earth 1984, 89, 6329-6340. [CrossRef]

44. Therien, C. Welcome to the PySptools Documentation. Available online: https://pysptools.sourceforge.io/ (accessed on 22 July 2020).

45. Cardoso-Fernandes, J.; Silva, J.; Dias, F.; Lima, A.; Teodoro, A.C.; Barrès, O.; Cauzid, J.; Perrotta, M.; Roda-Robles, E.; Ribeiro, M.A. Tools for Remote Exploration: A Lithium (Li) Dedicated Spectral Library of the Fregeneda-Almendra Aplite-Pegmatite Field. Data 2021, 6, 33. [CrossRef]

46. Cardoso-Fernandes, J.; Silva, J.; Dias, F.; Lima, A.; Teodoro, A.C.; Barrès, O.; Cauzid, J.; Perrotta, M.; Roda-Robles, E.; Ribeiro, M.A. Tools for Remote Exploration: A Lithium (Li) Dedicated Spectral Library of the Fregeneda-Almendra Aplite-Pegmatite Field; Zenodo: Meyrin, Switzerland, 2021. [CrossRef]

47. Hunt, G.R.; Salisbury, J.W. Visible and near-infrared spectra of minerals and rocks: I Silicate minerals. Mod. Geol. 1970, 1, 283-300.

48. Clark, R.N.; King, T.V.V.; Klejwa, M.; Swayze, G.A.; Vergo, N. High spectral resolution reflectance spectroscopy of minerals. J. Geophys. Res. Solid Earth 1990, 95, 12653-12680. [CrossRef]

49. Pontual, S.; Merry, N.J.; Gamson, P. Spectral Interpretation Field Manual: GMEX Spectral Analysis Guides for Mineral Exploration, 3rd ed.; AusSpec International Ltd.: Victoria, Australia, 2008; Volume 1.

50. Clark, R.N.; Swayze, G.A.; Gallagher, A.J.; King, T.V.V.; Calvin, W.M. The U. S. Geological Survey, Digital Spectral Library: Version 1 (0.2 to 3.0 um); Open-File Report 93-592; Geological Survey: Reston, WV, USA, 1993.

51. Mattson, S.M.; Rossman, G.R. $\mathrm{Fe}^{2+}-\mathrm{Fe}^{3+}$ interactions in tourmaline. Phys. Chem. Miner. 1987, 14, 163-171. [CrossRef] 
52. Clark, R.N. Chapter 1: Spectroscopy of rocks and minerals and principles of spectroscopy. In Remote Sensing for the Earth Sciences: Manual of Remote Sensing, 3rd ed.; Ryerson, R.A., Ed.; John Wiley \& Sons, Inc.: Hoboken, NJ, USA, 1999.

53. Hunt, G.R. Spectral signatures of particulate minerals in the visible and near infrared. Geophysics 1977, 42, 501-513. [CrossRef]

54. King, T.V.V.; Clark, R.N. Spectral characteristics of chlorites and Mg-serpentines using high-resolution reflectance spectroscopy. J. Geophys. Res. Solid Earth 1989, 94, 13997-14008. [CrossRef]

55. Clark, R.N.; Swayze, G.A.; Wise, R.; Livo, K.E.; Hoefen, T.M.; Kokaly, R.F.; Sutley, S.J. USGS Digital Spectral Library splib05a. Available online: https:/ / pubs.usgs.gov/of/2003/ofr-03-395/ (accessed on 8 January 2021).

56. Hunt, G.R.; Ashley, R.P. Spectra of altered rocks in the visible and near infrared. Econ. Geol. 1979, 74, 1613-1629. [CrossRef]

57. Cardoso-Fernandes, J.; Dias, F.; Lima, A.; Anjos Ribeiro, M.; Perrotta, M.; Roda-Robles, E.; Teodoro, A.C. Petalite alteration products from the Bajoca pegmatite (Central Portugal): A multiapproach for lithium exploration. In Proceedings of the EGU General Assembly 2021, Online, 19-30 April 2021. [CrossRef]

58. Lima, A. Estrutura, Mineralogia e Génese dos Filões Aplitopegmatíticos com Espodumena da Região do Barroso-Alvão. Ph.D. Thesis, Universidade do Porto, Porto, Portugal, 2000.

59. Lypaczewski, P.; Rivard, B. Estimating the Mg\# and AlVI content of biotite and chlorite from shortwave infrared reflectance spectroscopy: Predictive equations and recommendations for their use. Int. J. Appl. Earth Obs. Geoinf. 2018, 68, 116-126. [CrossRef]

60. Bishop, J.L.; Lane, M.D.; Dyar, M.D.; Brown, A.J. Reflectance and emission spectroscopy study of four groups of phyllosilicates: Smectites, kaolinite-serpentines, chlorites and micas. Clay Miner. 2008, 43, 35-54. [CrossRef]

61. Felzer, B.; Hauff, P.; Goetz, A.F.H. Quantitative reflectance spectroscopy of buddingtonite from the Cuprite mining district, Nevada. J. Geophys. Res. Solid Earth 1994, 99, 2887-2895. [CrossRef]

62. Krohn, M.D.; Altaner, S.P. Near-infrared detection of ammonium minerals. Geophysics 1987, 52, 924-930. [CrossRef]

63. Aires, S.C.M. Petrofísica e Litogeoquímica de Formações do "Complexo Xisto-Grauváquico" (Grupo do Douro) Estudo do Potencial do "Xisto" Para Exploração Como Pedra Natural. Ph.D. Thesis, Faculdade de Ciências da Universidade do Porto, Porto, Portugal, 2018.

64. Duke, E.F. Near infrared spectra of muscovite, Tschermak substitution, and metamorphic reaction progress: Implications for remote sensing. Geology 1994, 22, 621-624. [CrossRef]

65. Ellis, R.J.; Scott, P.W. Evaluation of hyperspectral remote sensing as a means of environmental monitoring in the St. Austell China clay (kaolin) region, Cornwall, UK. Remote Sens. Environ. 2004, 93, 118-130. [CrossRef]

66. Oshigami, S.; Yamaguchi, Y.; Uezato, T.; Momose, A.; Arvelyna, Y.; Kawakami, Y.; Yajima, T.; Miyatake, S.; Nguno, A. Mineralogical mapping of southern Namibia by application of continuum-removal MSAM method to the HyMap data. Int. J. Remote Sens. 2013, 34, 5282-5295. [CrossRef]

67. Deer, W.A.; Howie, R.A.; Zussman, J. Rock-Forming Minerals: Single-Chain Silicates, 2nd ed.; The Geological Society: London, UK, 1978; Volume 2A, p. 668.

68. London, D.; Burt, D.M. Chemical models for lithium aluminosilicate stabilities in pegmatites and granites. Am. Mineral. 1982, $67,494-509$.

69. Dill, H.G. A geological and mineralogical review of clay mineral deposits and phyllosilicate ore guides in Central Europe-A function of geodynamics and climate change. Ore Geol. Rev. 2020, 119, 103304. [CrossRef]

70. Cerny, P. The Tanco pegmatite at Bernic Lake, Manitoba; VIII, Secondary minerals from the spodumene-rich zones. Can. Mineral. 1972, 11, 714-726.

71. Asadzadeh, S.; Souza Filho, C.R. A review on spectral processing methods for geological remote sensing. Int. J. Appl. Earth Obs. Geoinf. 2016, 47, 69-90. [CrossRef]

72. Quensel, P. Minerals of the Varuträsk Pegmatite: IV. Petalite and its Alteration Product, Montmorillonite. Geol. Fören. Stockh. Förh. 1937, 59, 150-156. [CrossRef]

73. Quensel, P. Minerals of the Varuträsk Pegmatite: X. Spodumene and its Alteration Products. Geol. Fören. Stockh. Förh. 1938, 60, 201-215. [CrossRef]

74. Foster, M.D. Interpretation of the Composition of Lithium Micas; United States Geological Survey Professional Paper: Washington, DC, USA, 1960; pp. 115-147. 